Review Article

\title{
Mechanical Properties of Titanium Diboride Particles Reinforced Aluminum Alloy Matrix Composites: A Comprehensive Review
}

\author{
V. Mohanavel $\left(\mathbb{D},{ }^{1}\right.$ M. Ravichandran ${ }^{D},{ }^{2}$ V. Anandakrishnan $\left(\mathbb{D},{ }^{3}\right.$ Alokesh Pramanik, \\ M. Meignanamoorthy, ${ }^{2}$ Alagar Karthick $\left(10,{ }^{5}\right.$ and M. Muhibbullah $\mathbb{1}^{6}$ \\ ${ }^{1}$ Centre for Materials Engineering and Regenerative Medicine, Bharath Institute of Higher Education and Research, \\ Chennai 600073, Tamil Nadu, India \\ ${ }^{2}$ Department of Mechanical Engineering, K. Ramakrishnan College of Engineering, Trichy 621 112, Tamil Nadu, India \\ ${ }^{3}$ Department of Production Engineering, National Institute of Technology, Trichy 620015, Tamil Nadu, India \\ ${ }^{4}$ School of Civil and Mechanical Engineering, Curtin University, Perth, Australia \\ ${ }^{5}$ Renewable Energy Lab, Department of Electrical and Electronics Engineering, KPR Institute of Engineering and Technology, \\ Arasur, Coimbatore 641407, Tamil Nadu, India \\ ${ }^{6}$ Department of Electrical and Electronic Engineering, Bangladesh University, Dhaka 1207, Bangladesh
}

Correspondence should be addressed to V. Mohanavel; mohanavel2k16@gmail.com

Received 5 August 2021; Accepted 22 November 2021; Published 23 December 2021

Academic Editor: Ivan Giorgio

Copyright (C) 2021 V. Mohanavel et al. This is an open access article distributed under the Creative Commons Attribution License, which permits unrestricted use, distribution, and reproduction in any medium, provided the original work is properly cited.

Aluminum alloys with silicon, magnesium, and copper were extensively used alloying elements in various applications because of their excellent properties. In recent decades, aluminum matrix composites (AMCs) are an advanced engineering material widely utilized in diverse engineering applications, including aircraft, automobile, marine, and shipbuilding, owing to their low density, lightweight, good stiffness, superior strength, and good tribological properties. Aluminum is abundant and its use is as vast as the ocean. It is also the most used matrix material in the composite arena. Therefore, incorporating a ceramic particle into a relatively soft aluminum matrix improves hardness, strength, stiffness, creep, fatigue, and wear properties instead of the conventional materials. This article is an assay to review and spotlight some recent works on the mechanical behaviors of aluminum-based titanium diboride reinforced metal matrix composite. This review article concentrates on the mechanical properties and the fabrication processes of $\mathrm{Al}_{-}-\mathrm{TiB}_{2}$ composites to provide a valuable reference to nurture future research precisely.

\section{Introduction}

In the past few decades, aluminum matrix composite has acted an essential role in material science, especially in aircraft, marine, automobile, transportation, and defense sectors [1]. Several investigations have reported that the inclusion of ceramic filler contents to the matrix improves the mechanical, physical, and tribological properties [2]. Aluminum matrices that are incorporated with hard ceramic filler contents expose the augmented mechanical properties as compared to the plain alloy materials [3]. Figure 1 exhibits the list of wrought aluminum alloy. Due to their high strength-to-weight ratio, high thermal conductivity, good corrosion resistance, and improved mechanical properties, aluminum metal matrix composites (AMCs) are increasingly used as structural materials. Composite materials are becoming more popular due to their unique properties and high strength-to-weight ratio. Ceramic particles provide exceptional strength and wear resistance to AMCs [4-6]. Figure 2 reveals the classification of aluminum composites fabrication process. A large range of filler particles such as $\mathrm{SiC}, \mathrm{Si}_{3} \mathrm{~N}_{4}, \mathrm{ZrN}, \mathrm{TiN}, \mathrm{TiB}_{2}, \mathrm{Al}_{2} \mathrm{O}_{3}, \mathrm{BN}$, WC, and $\mathrm{SiO}_{2}$ has used the reinforcements for the manufacture of composites. Amid the other filler materials, titanium diboride $\left(\mathrm{TiB}_{2}\right)$ is a promising candidate filler material for aluminum-based composites. It exhibits an enticing combination of mechanical and physical properties, superior 


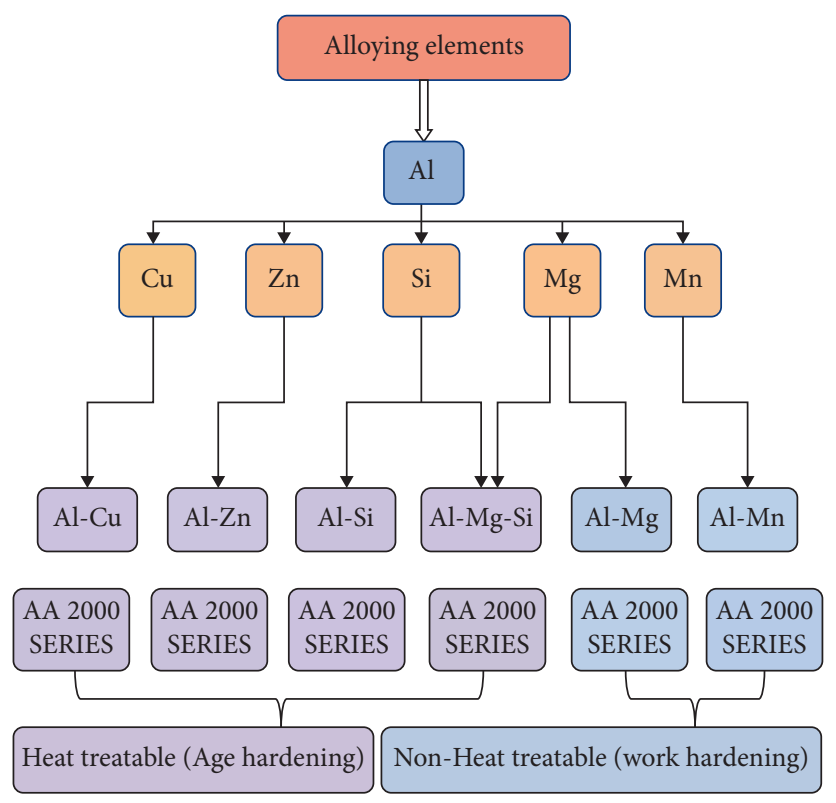

Figure 1: List of wrought aluminum alloy.

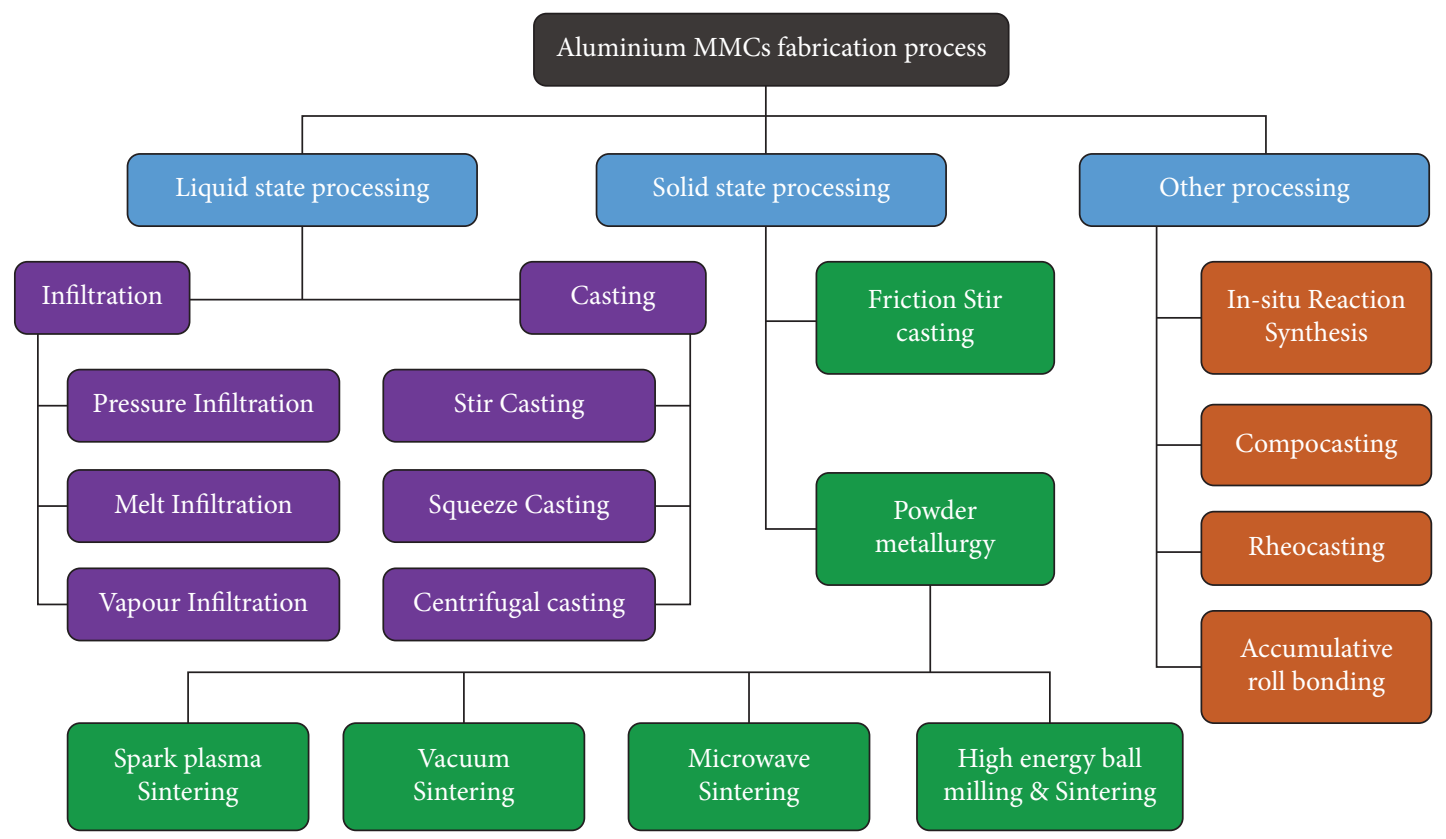

FIgURE 2: Classification of aluminum composites fabrication process.

strength, perfect hardness, high melting point, excellent corrosion resistance, and excellent wear protection [7-10]. Figure 3 illustrates the advantages and disadvantages of different techniques for composites.

Titanium diboride $\left(\mathrm{TiB}_{2}\right)$ particle does not react with molten aluminum and cannot form reaction products at the intergap between matrix and reinforcement [11]. Compared with the other filler contents, $\mathrm{TiB}_{2}$ is a desirable strengthening agent for aluminum-based metal matrix composites [12]. Titanium diboride based aluminum matrix composites were recently employed in the manufacturing of automobile piston, vehicle drive shaft, cylinder liners, cutting tools, crank shaft, brake drum, and bicycle frames and were also employed in aerospace, marine, and automotive industries because of their good stiffness, superior strength, high temperature stability, and lightweight [13]. AMCs have been fabricated using a variety of methods like compocasting, melt stirring casting, powder metallurgy, in situ casting, squeeze casting, and spray forming and mechanical alloying methods. Figures 4(a)-4(c) reveal the schematic diagram of stir casting, powder metallurgy, and hot extrusion process.

Liquid state processing method contains incorporation of ceramic particles externally or formed inside the molten metal. The former is known as ex situ (stir casting technique) 


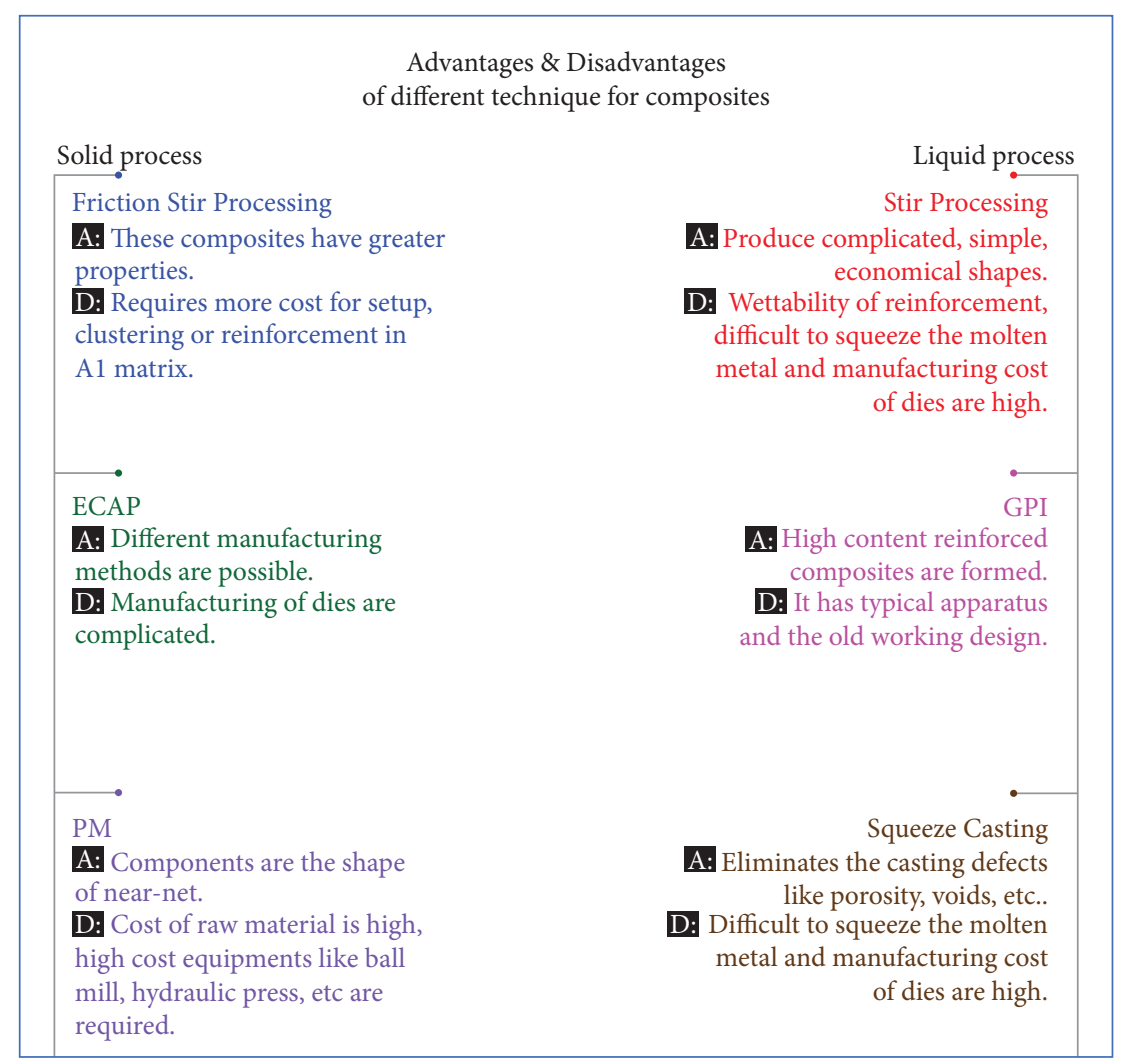

Figure 3: Advantages and disadvantages of different techniques for composites.

while the latter is called as in situ (direct melt reaction technique or exothermic salt-metal reaction technique) fabrication. Liquid state casting techniques have shown some incomparable benefits like constant dissemination of filler particles in the matrix and strong interfacial attachment between the matrix and the filler particle [14]. Figure 5 reveals the classification of fabrication method of AMCs.

Figure 6 exhibits the influence of various parameters on hardness. A number of researchers have produced titanium diboride reinforced AMCs using various techniques. This scientific review article provides an aerial view of research efforts that are focused on mechanical properties and synthesizing techniques of aluminum-based titanium diboride composites. Table 1 reveals the physical and mechanical properties of several ceramics reinforcements. The SEM image of the $\mathrm{TiB}_{2}$ particles is depicted in Figure 7.

\section{Fabrication Techniques of Al-TiB $_{2}$ Composites}

Among the several manufacturing techniques, the two techniques that are being used quite often are in situ casting and stir casting. Figure 8 reveals the process parameters influence the production of composites through the melt stirring route.

2.1. Stir Casting. The processing route is the most significant consideration in the fabrication of AMCs. In 1968, $\mathrm{S}$. Ray dispersed alumina $\left(\mathrm{Al}_{2} \mathrm{O}_{3}\right)$ ceramic filler materials into the $\mathrm{Al}$ melt, and in this process the incorporated filler material is blended with a molten state alloy by means of mechanical stirring [15]. For the processing of discontinuous rein-forced AMCs, several researchers prefer to employ stir casting route. The foremost objective of melt stirring is that it is trouble-free, flexible, unproblematic, reasonable, and appropriate for bulk production [16, 17]. Mohanavel et al. [18] utilized melt stirring to manufacture AA6351/SiC AMCs. SEM images of the resultant AA6351/ SiC AMCs comprising 4\%, $8 \%$, and $12 \% \mathrm{SiC}$, respectively, are revealed in Figures 9(a)-9(c). The SEM images demonstrate a nearly homogeneous dispersion of the $\mathrm{SiC}$ in the AA6351 alloy. Moreover, the stir casting is affordable and provides an efficient stirring movement in the melts due to the sound particle-matrix association in the filler material. The cast-on route for the development of inhomogeneous filler in integrated MMCs is the most widely used liquid state casting process. Figure 10 reveals the experimental structure for the fabrication of composites through melt stirring route.

2.2. In Situ Casting. The in situ technique has been an attractive processing route for producing AMCs. In situ synthesizing technique was started in the early 1990s. In this process in situ reaction between the halide salts and molten metal takes place to form reinforcement particles. Exothermic method is more effective than the stir casting process $[19,20]$. In situ formed reinforcement exhibits homogeneous dissemination of fine sized filler materials. It 


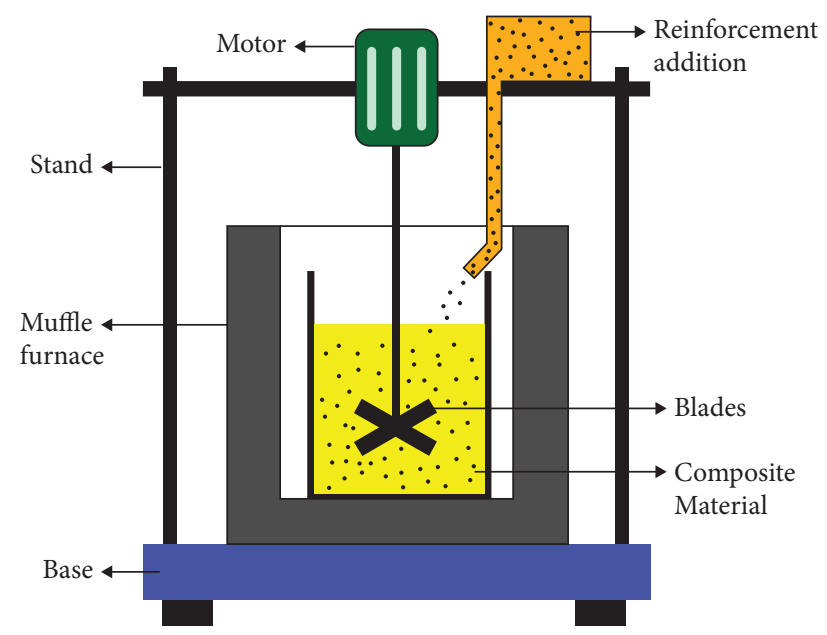

(a)
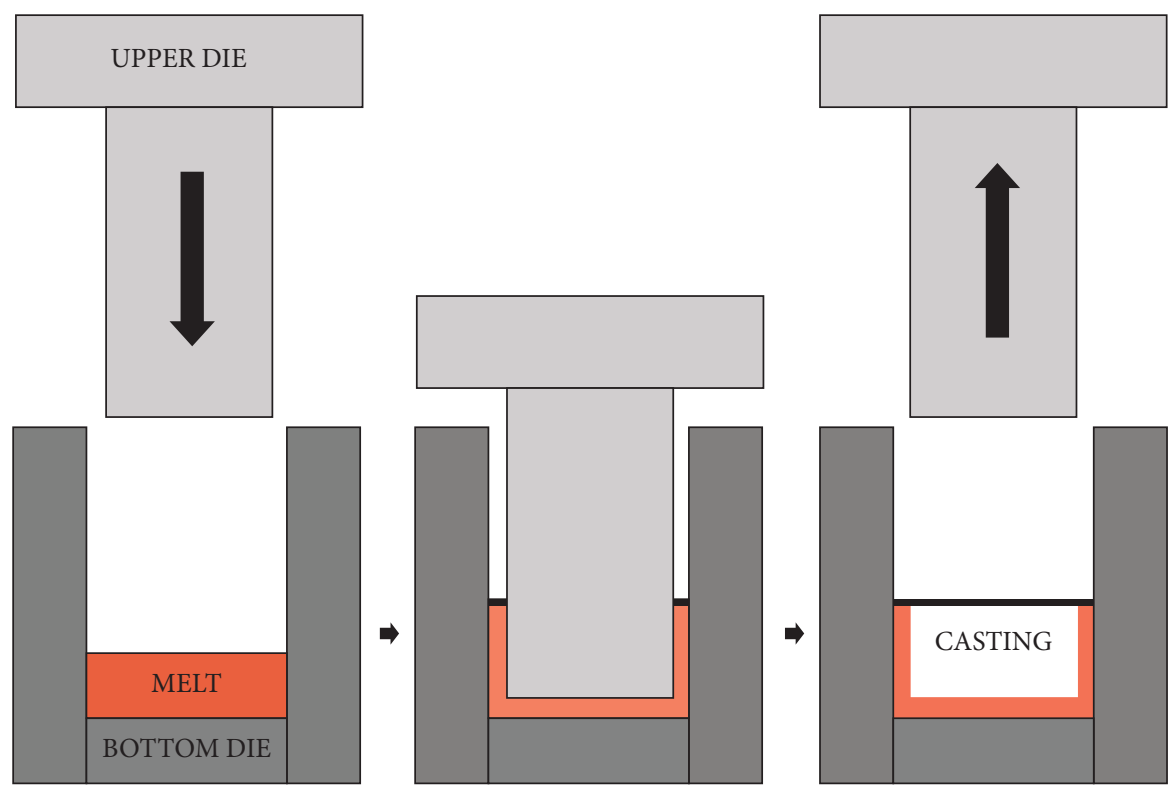

(b)

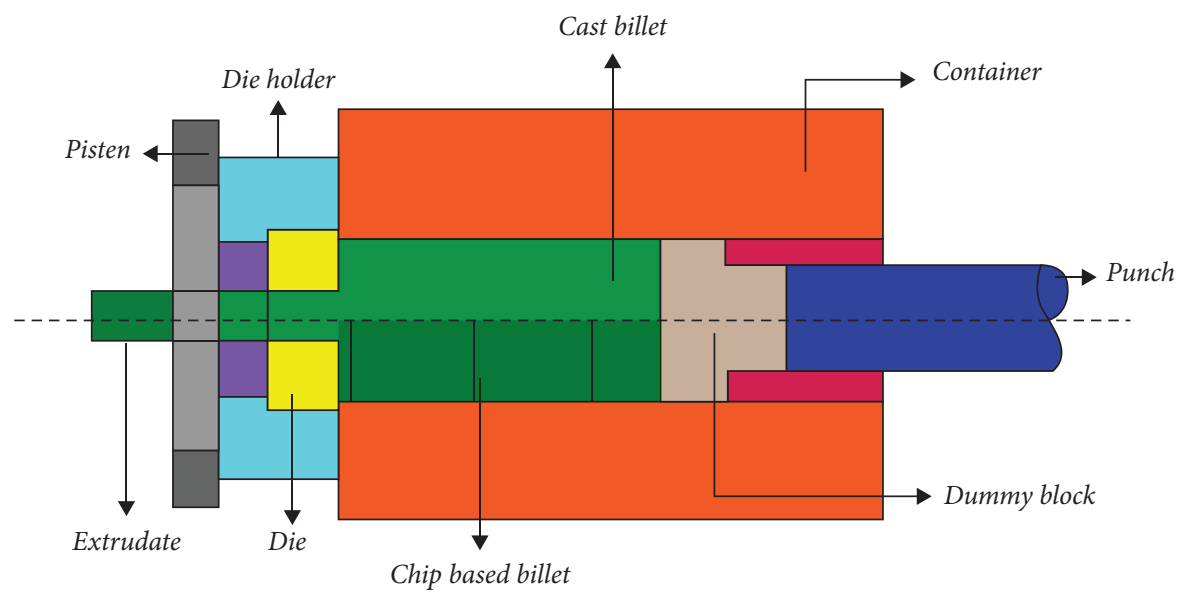

(c)

Figure 4: Schematic diagram of fabrication process: (a) stir casting, (b) powder metallurgy, and (c) hot extrusion. 


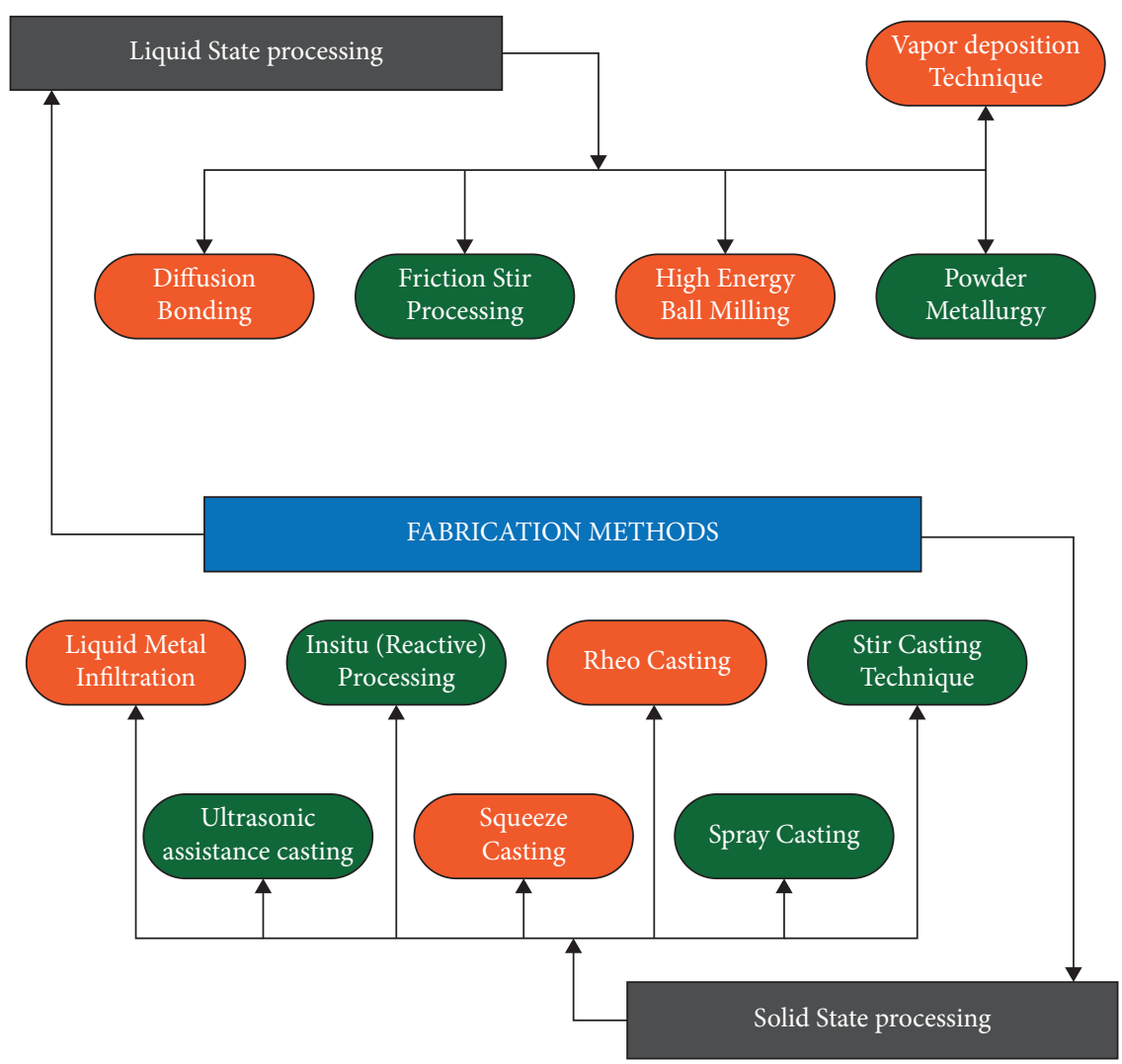

FIgURE 5: Classification of fabrication method of AMCs.

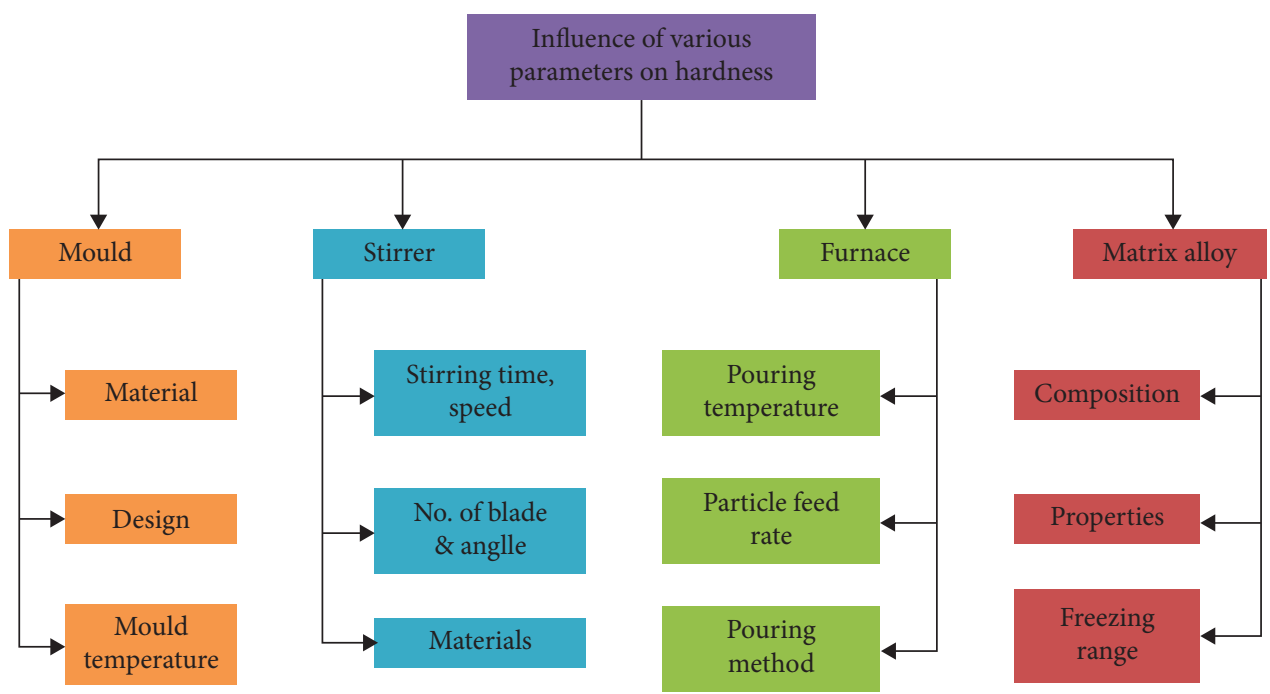

FIGURE 6: Influence of various parameters on hardness.

TABLe 1: Physical and mechanical properties of several ceramics reinforcements.

\begin{tabular}{lccccc}
\hline Sl. no & Properties & $\mathrm{TiC}$ & $\mathrm{B}_{4} \mathrm{C}$ & $\mathrm{ZrB}_{2}$ & $\mathrm{TiB}_{2}$ \\
\hline 1 & Melting point $\left({ }^{\circ} \mathrm{C}\right)$ & 2830 & 2780 & 3040 & 3225 \\
2 & Density $\left(\mathrm{g} \mathrm{cm}^{-3}\right)$ & 4.77 & 2.52 & 6.08 & 3.52 \\
3 & Hardness $(\mathrm{GPa})$ & $22-24$ & $18-20$ & $25-35$ \\
4 & Thermal conductivity $\left(\mathrm{Wm}^{-1} \mathrm{~K}^{-1}\right)$ & 31.8 & 32.5 & $60-27$ & $69-120$ \\
5 & Molar mass $(\mathrm{g} / \mathrm{mol})$ & 59.89 & 52.255 & 112.85 & Hexagonal \\
6 & Crystal structure & Cubic & Rhombohedral & Hexagonal \\
6 & Elastic modulus $(\mathrm{GPa})$ & 450 & 472 & 560 \\
\hline
\end{tabular}




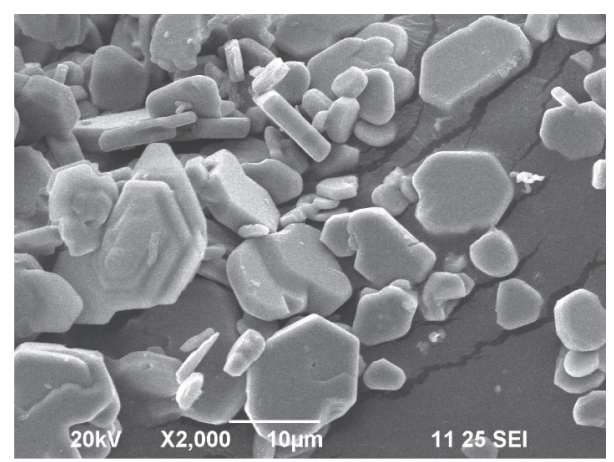

FIGURE 7: SEM image of $\mathrm{TiB}_{2}$ particles.

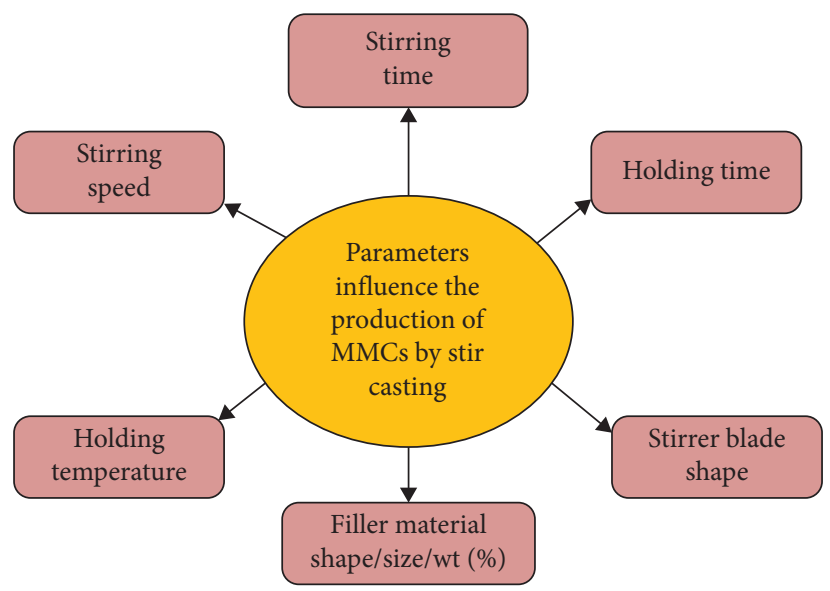

FIGURE 8: Process parameters influence the production of composites through the melt stirring route.

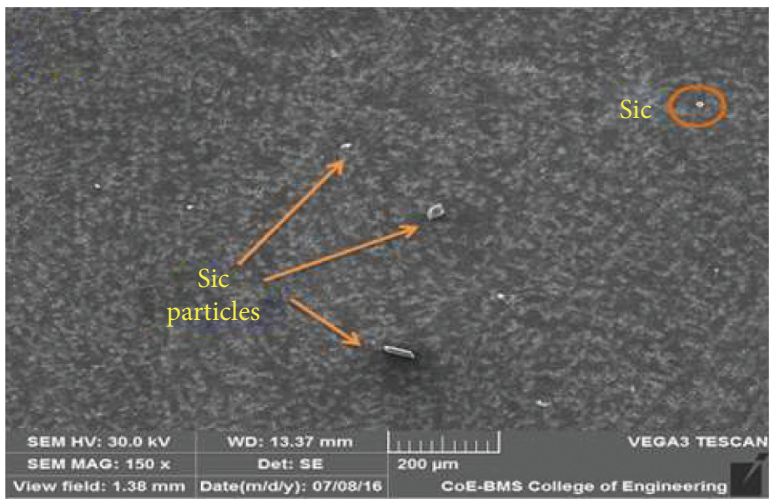

(a)

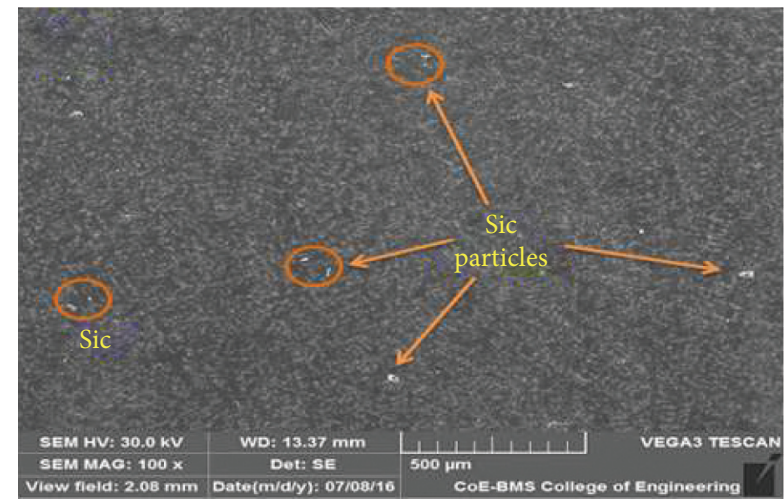

(b)

Figure 9: Continued. 


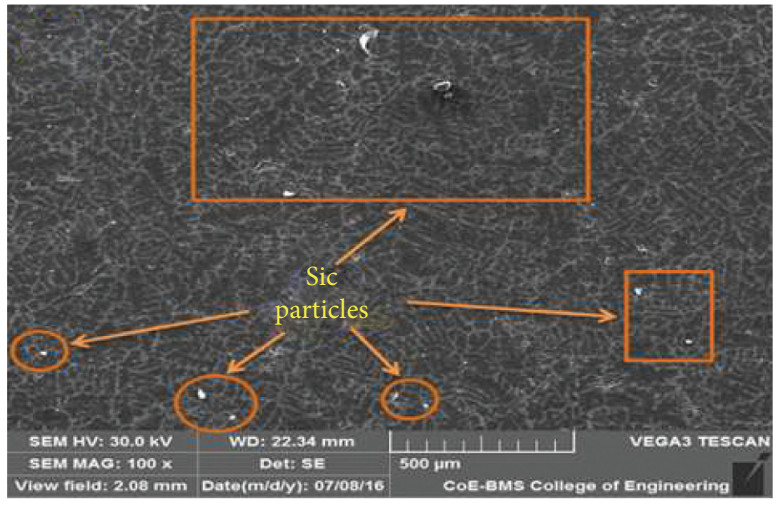

(c)

Figure 9: SEM images of (a) Al6351/4 wt\% SiC AMCs, (b) Al6351/8 wt\% SiC AMCs, and (c) Al6351/12 wt\% SiC AMCs [18].

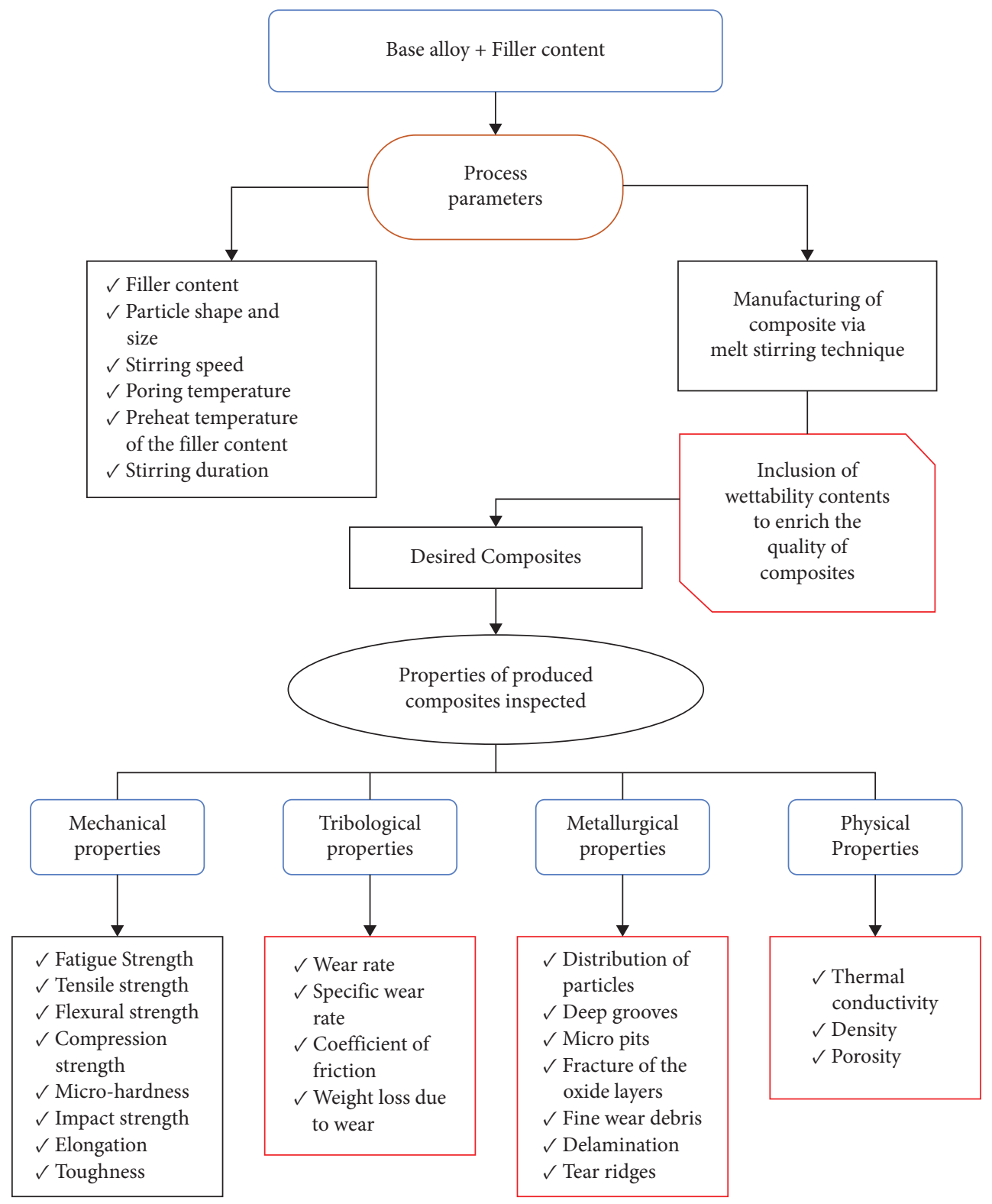

FIGURE 10: Experimental structure for the fabrication of composites through melt stirring route. 


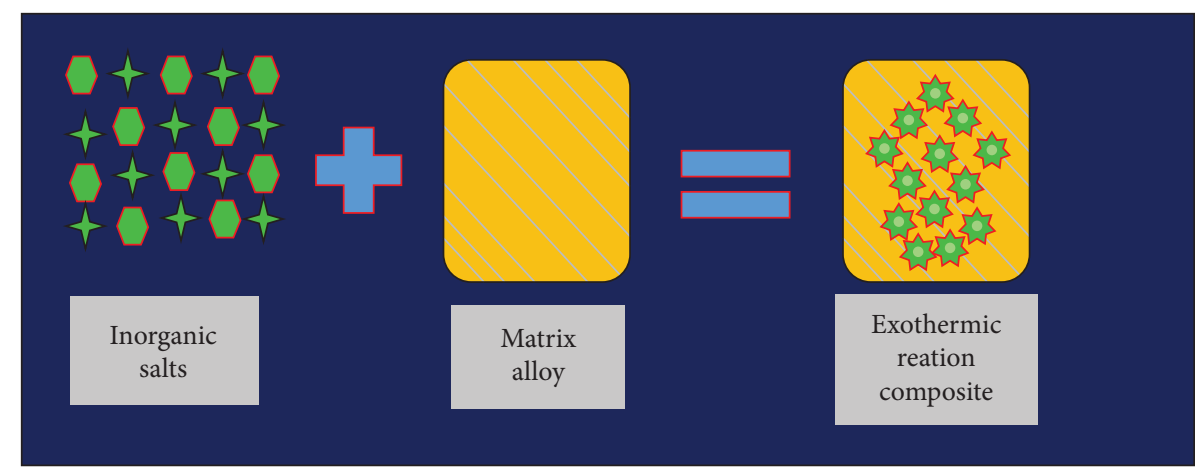

FIgURE 11: Manufacturing of in situ composite employing inorganic salts and aluminum matrix alloy.

is effortlessly accomplished without the need for incorporation of wetting agent. The in situ reactions, as provided in the following equations, resulted in the generation of $\mathrm{TiB}_{2}$ particles. Consider the following:

$$
\begin{gathered}
\mathrm{K}_{2} \mathrm{TiF}_{6}+\frac{13}{2} \mathrm{Al} \longrightarrow \mathrm{Al}_{3} \mathrm{Ti}+\frac{4}{3} \mathrm{AlF}_{3}+2 \mathrm{KF} \\
2 \mathrm{KBF}_{4}+3 \mathrm{Al} \longrightarrow \mathrm{AlB}_{2}+2 \mathrm{AlF}_{3}+2 \mathrm{KF} \\
\mathrm{Al}_{3} \mathrm{Ti}+\mathrm{AlB}_{2} \longrightarrow \mathrm{TiB}_{2}+4 \mathrm{Al}
\end{gathered}
$$

The formation pattern of $\mathrm{TiB}_{2}$ can be classified as follows. (a) The incorporation of $\mathrm{K}_{2} \mathrm{TiF}_{6}$ (potassium hexafluorotitanate) and $\mathrm{KBF}_{4}$ (potassium tetrafluoroborate) to molten aluminum generates intermetallic compounds, specifically $\mathrm{Al}_{3} \mathrm{Ti}$ and $\mathrm{AlB}_{2}$, which serve as for Ti and $\mathrm{B}$ atoms. (b) Boron atoms travel in the direction of particles from $\mathrm{Al}_{3}$ Ti. (c) The reaction occurred between atoms Ti and $\mathrm{B}$ in a gap from the surface of $\mathrm{Al}_{3} \mathrm{Ti}$ to form $\mathrm{TiB}_{2}$. (d) Boron atoms begin diffusing into $\mathrm{TiB}_{2}$ particles because of the smaller scale. (e) Dissolution of $\mathrm{Al}_{3} \mathrm{Ti}$ particle owing to normal cracking and fragmentation of $\mathrm{Al}_{3} \mathrm{Ti}$ particles, which contribute to enriched $\mathrm{TiB}_{2}$ generation rate. (f) Generation of $\mathrm{TiB}_{2}$ particles, after the entire reaction. Moreover, the $\mathrm{KBF}_{4}$ inorganic salt was incorporated slightly in excess of the stoichiometric ratio to avoid the formation of titanium trialuminide $\left(\mathrm{Al}_{3} \mathrm{Ti}\right)$. Figure 11 reveals the manufacturing of in situ composite employing inorganic salts and aluminum matrix alloy.

In preparing AMCs, "in situ” techniques offer significant advantages over the conventional processing routes and in situ casting route is more economical. In situ type of processing is now in commercial use for $\mathrm{TiB}_{2}$ particle reinforced aluminum matrix composites [21-23]. Moreover, the $\mathrm{TiB}_{2}$ reinforcement particles in the composite inhibit dislocations, resulting in higher tensile strength. This interface allows for an efficient load transfer between the matrix alloy and the reinforcement. As the $\mathrm{TiB}_{2}$ particle content increases, this composite has higher mechanical properties than pure aluminum alloy [22]. Figure 12 displays the experimental arrangement of in situ casting. In [23], the dry sliding wear parameters on $\mathrm{LM}_{4} / \mathrm{TiB}_{2}$ composites were analyzed using the Taguchi method. Particulates reinforced

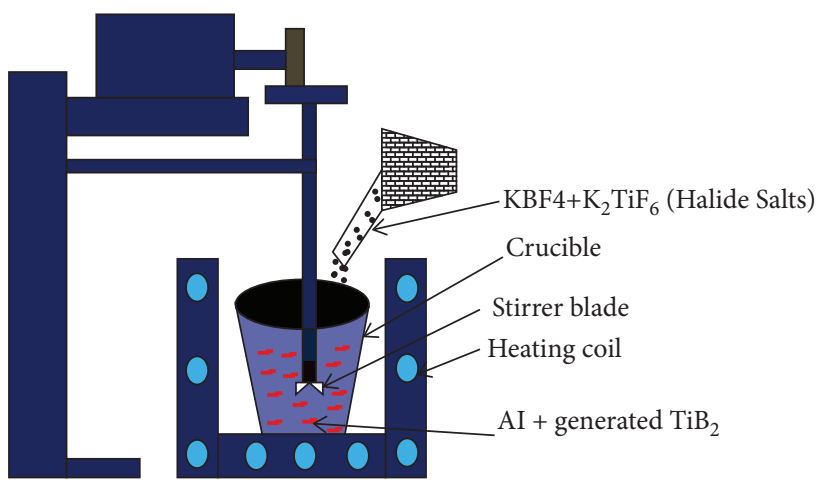

Figure 12: Experimental arrangement of $\mathrm{Al}-\mathrm{TiB}_{2}$ in situ composite.

aluminum matrix composite has better tribological properties compared to unreinforced aluminum matrix composite. Mohanavel et al. [21] employed in situ casting to manufacture AA6351/TiB 2 AMCs. Microhardness and strength increase with the enhancement of the weight percentages of $\mathrm{TiB}_{2}$ particles. SEM micrographs of the resultant $\mathrm{AA} 6351 / \mathrm{TiB}_{2} \mathrm{AMCs}$ comprising 0\%, 4\%, and $8 \%$ $\mathrm{TiB}_{2}$, respectively, are revealed in Figures 13(a)-13(e). The SEM micrographs demonstrate a homogeneous dispersion of the $\mathrm{TiB}_{2}$ in the AA6351 alloy.

\section{Comparison of In Situ versus Stir Casting}

Table 2 explicates results obtained by various researchers where $\mathrm{TiB}_{2}$ is the reinforcement and the processes involved mostly are in situ and stir casting and the percentages at which superior mechanical properties emerge are spotted in Table 3. Both in situ and stir casting method can fabricate Al$\mathrm{TiB}_{2}$ composites with strong mechanical and wear properties. Most of the explorations have been done on titanium diboride filler particle for aluminum based in situ AMCs. Titanium diboride reinforced aluminum matrix composites are fabricated using halide salt reaction technique and it has proven to be cost effective [24]. $\mathrm{Al}^{-\mathrm{TiB}_{2}}$ in situ composites are usually synthesized by the incorporation of inorganic salts like $\mathrm{K}_{2} \mathrm{TiF}_{6}$ and $\mathrm{KBF}_{4}$ which react with molten aluminum and form $\mathrm{TiB}_{2}$ in the Al melt [25-30]. The $\mathrm{Al}-\mathrm{TiB}_{2}$ in situ AMCs reveal superior mechanical and tribological 

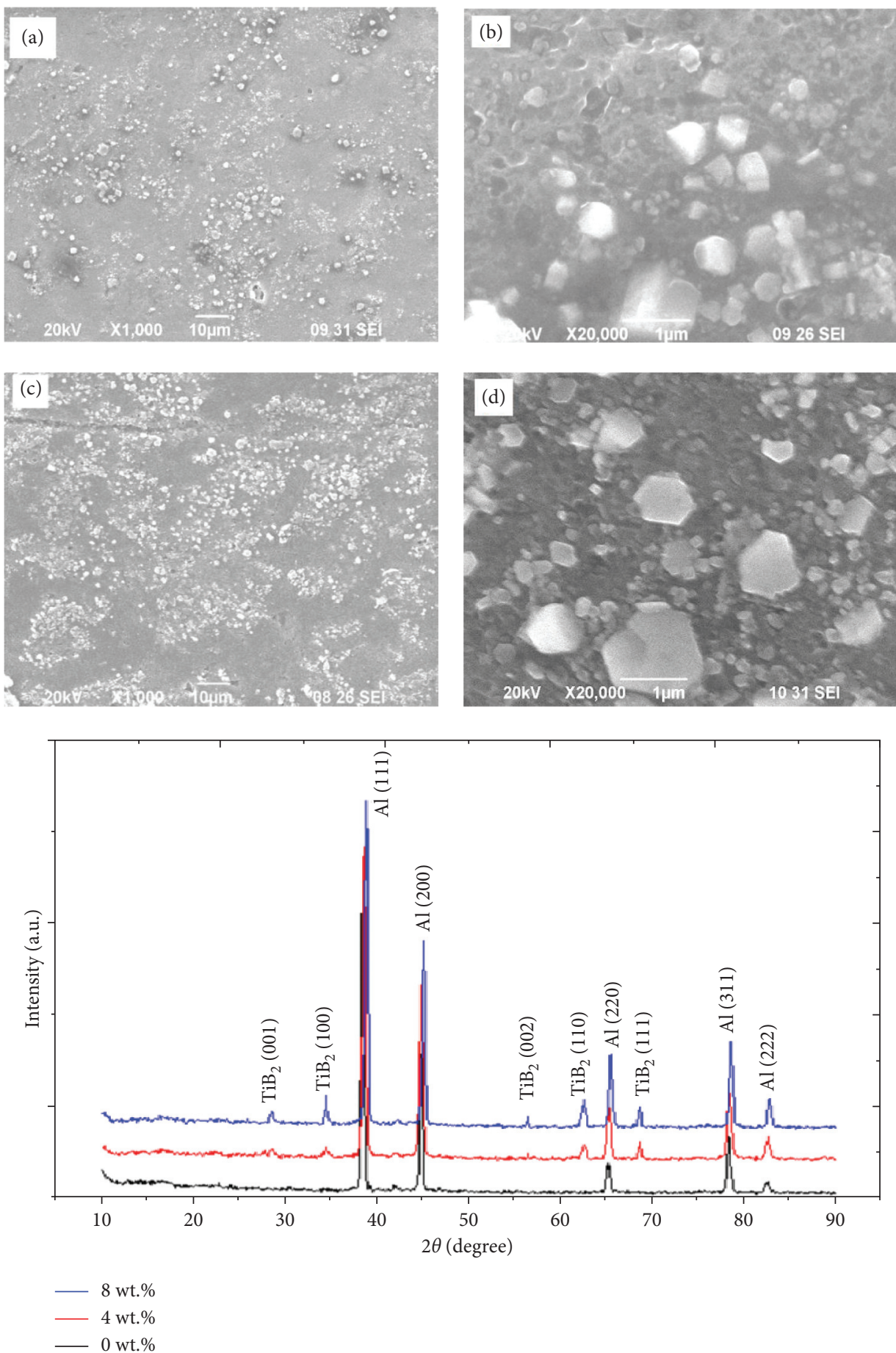

(e)

FIgURE 13: SEM micrograph of AA6351/TiB $\mathrm{AMCs}_{2}$ containing: (a) $4 \% \mathrm{TiB}_{2}$, (b) $4 \% \mathrm{TiB}_{2}$, (c) $8 \% \mathrm{TiB}_{2}$, (d) $8 \% \mathrm{TiB}_{2}$, and (e) XRD patterns of AA6351/TiB 2 in situ composites [21].

properties compared with the base matrix alloy. In situ technique offers high mechanical bonding, homogeneous dissemination of small size of fillers in the matrix, thermodynamic stability, and clear interfacing between the solid and liquid in contrast to stir casting $[31,32]$. $\mathrm{TiB}_{2}$ involved composites have utilized stir casting, squeeze casting, centrifugal casting, and compocasting rarely. It is also more economical when compared to in situ casting. Mechanical and physical properties like density, porosity, flexural strength, and compression strength are analyzed by a few researchers only, where $\mathrm{TiB}_{2}$ plays a vital role as reinforcement. 
TABLe 2: Titanium diboride reinforced composites properties.

\begin{tabular}{|c|c|c|c|c|}
\hline MMC within (wt \%) & $\begin{array}{l}\text { Manufacturing } \\
\text { process }\end{array}$ & Mechanical properties & Remarks & Reference \\
\hline $\begin{array}{l}\mathrm{Al} 6061-\mathrm{TiB}_{2}(0,4.98,9.29, \\
13.62 \mathrm{wt} \%)\end{array}$ & In situ casting & $\begin{array}{l}\text { Microhardness, } \\
\text { ultimate tensile } \\
\text { strength }\end{array}$ & $\begin{array}{l}\text { Hardness and tensile strength of the } \\
\text { composite enhanced as compared to } \\
\text { nonreinforced plain alloy matrix. }\end{array}$ & {$[33]$} \\
\hline $\mathrm{AA} 6061-\mathrm{TiB}_{2}(0,12$ wt \%) & In situ casting & $\begin{array}{c}\text { Brinell hardness, UTS, } \\
\% \text { elongation }\end{array}$ & $\begin{array}{l}\text { All these mechanical characteristics of } \\
\text { the AMCs were superior to those of } \\
\text { pure } \mathrm{Al} \text { matrix alloy. The incorporation } \\
\text { of } \mathrm{TiB}_{2} \text { filler contents into the AA6061 } \\
\text { alloy has diminished the elongation of } \\
\text { the composite. }\end{array}$ & {$[34]$} \\
\hline $\mathrm{Al}^{-\mathrm{TiB}_{2}}(1,4,7$ wt \%) & $\begin{array}{l}\text { Salt-metal reaction } \\
\text { route }\end{array}$ & Hardness, UTS & $\begin{array}{l}\text { All these mechanical properties of the } \\
\text { AMCs were superior to those of plain } \\
\text { aluminum. }\end{array}$ & {$[35]$} \\
\hline $\mathrm{A} 356-\mathrm{TiB}_{2}(0,2.12,4.66,8.37$ wt \%) & $\begin{array}{l}\text { In situ reaction } \\
\text { process }\end{array}$ & UTS, YS, elongation & $\begin{array}{c}\text { Mechanical behaviors of the AMCs } \\
\text { were greater than those of plain alloy } \\
\text { but superior testing results are obtained } \\
\text { at } 8.37 \text { vol\% of } \mathrm{TiB}_{2} \text { reinforced } \\
\text { composites. }\end{array}$ & {$[36]$} \\
\hline $\mathrm{AA} 2219-\mathrm{TiB}_{2}(0,5,10 \mathrm{wt} \%)$ & In situ route & $\begin{array}{l}\text { Hardness, UTS, YS, } \\
\text { and elongation }\end{array}$ & $\begin{array}{l}\text { Both hardness and UTS are being } \\
\text { increased when the mass concentration } \\
\text { of } \mathrm{TiB}_{2} \text { filler contents reached up to } \\
10 \% \text {. Addition of } \mathrm{TiB}_{2} \text { reduced the } \\
\text { elongation of the plain matrix alloy. } \\
\text { Hardness and tensile strength }\end{array}$ & {$[37]$} \\
\hline $\begin{array}{l}\mathrm{Al} 6063-\mathrm{TiB}_{2}(0,4.29,9.15 \text {, } \\
13.12 \text { wt \%) }\end{array}$ & In situ casting & $\begin{array}{l}\text { Hardness and tensile } \\
\text { strength }\end{array}$ & $\begin{array}{l}\text { properties are improved with the } \\
\text { augmented content of hard titanium } \\
\text { boride reinforcement. }\end{array}$ & {$[38]$} \\
\hline $\mathrm{Al} 6061-\mathrm{TiB}_{2}(0,2,4,6,8,10 \mathrm{wt} \%)$ & $\begin{array}{l}\text { High energy metal } \\
\text { stirring route }\end{array}$ & Hardness, UTS & $\begin{array}{l}\text { Hardness and UTS of the developed } \\
\text { AMCs were superior to those of base } \\
\text { matrix but better results are obtained at } \\
\text { the maximum percentage of } \mathrm{TiB}_{2} \\
\text { reinforced composite. }\end{array}$ & {$[39]$} \\
\hline $\mathrm{AA} 7075-\mathrm{TiB}_{2}(0,3,6,9 \mathrm{wt} \%)$ & $\begin{array}{l}\text { Exothermic reaction } \\
\text { process }\end{array}$ & $\begin{array}{c}\text { Microhardness, UTS, \% } \\
\text { elongation }\end{array}$ & $\begin{array}{l}\text { Both the UTS and the microhardness } \\
\text { were enriched as compared to pure } \mathrm{Al} \\
\text { matrix. Incorporation of hard } \mathrm{TiB}_{2} \\
\text { reduced the elongation of the base } \\
\text { matrix. }\end{array}$ & {$[40]$} \\
\hline $\mathrm{Al} 6063 / \mathrm{TiB}_{2}(0,5,10 \mathrm{wt} \%)$ & $\begin{array}{l}\text { Salt base exothermic } \\
\text { reaction process }\end{array}$ & Microhardness & $\begin{array}{l}\text { Microhardness of the produced } \\
\text { composite increased steadily as hard } \\
\mathrm{TiB}_{2} \text { reinforcement content increased. }\end{array}$ & {$[41]$} \\
\hline $\mathrm{A}_{356}-\mathrm{TiB}_{2}(0,12.5 \mathrm{wt} \%)$ & In situ casting process & $\begin{array}{l}\text { Ultimate tensile } \\
\text { strength, yield strength. }\end{array}$ & $\begin{array}{l}\text { Yield strength and tensile strength of } \\
\text { the aluminum metal matrix composites } \\
\text { were higher than those of unreinforced } \\
\text { plain matrix alloy and then increased } \\
\text { with the increase in the content of } \mathrm{TiB}_{2} \\
\text { particle. }\end{array}$ & {$[42]$} \\
\hline $\mathrm{AA} 6061-\mathrm{TiB}_{2}(0,4,8,12 \mathrm{wt} \%)$ & Stir casting & $\begin{array}{l}\text { Hardness, tensile } \\
\text { strength }\end{array}$ & $\begin{array}{l}\text { The tensile strength and the } \\
\text { microhardness of the prepared } \\
\text { composite tend to increase with the } \\
\text { increase in } \mathrm{TiB}_{2} \text { content. }\end{array}$ & {$[43]$} \\
\hline $\begin{array}{l}\text { Al-6Cu-0.2Mg-Mn- } \mathrm{TiB}_{2}(0,1,3 \text {, } \\
5 \mathrm{wt} \%)\end{array}$ & In situ casting & Microhardness & $\begin{array}{l}\text { Microhardness was greater than that of } \\
\text { base matrix alloy. The variation in the } \\
\text { presence of reinforcement particles is } \\
\text { visible with increased content of } \mathrm{TiB}_{2} \text {. } \\
\text { AA6061/10 wt } \% \mathrm{TiB}_{2} \text { AMC exhibits }\end{array}$ & {$[44]$} \\
\hline $\mathrm{AA} 6061-\mathrm{TiB}_{2}(10 \mathrm{wt} \%)$ & Stir casting & $\begin{array}{l}\text { Hardness and tensile } \\
\text { strength }\end{array}$ & $\begin{array}{l}58 \mathrm{HV} \text { of microhardness and } 195 \mathrm{MPa} \\
\text { of tensile strength. These AMCs are } \\
\text { fabricated in liquid state by stir casting } \\
\text { method. }\end{array}$ & {$[45]$} \\
\hline
\end{tabular}


TABle 2: Continued.

\begin{tabular}{|c|c|c|c|c|}
\hline MMC within (wt \%) & $\begin{array}{l}\text { Manufacturing } \\
\text { process }\end{array}$ & Mechanical properties & Remarks & Reference \\
\hline $\mathrm{A} 390-\mathrm{TiB}_{2}$ & In situ casting & $\begin{array}{c}\text { Hardness, UTS, and \% } \\
\text { elongation }\end{array}$ & $\begin{array}{l}\text { Ultimate tensile strength, ductility, and } \\
\text { hardness of the produced composite } \\
\text { were greater than those of } \\
\text { nonreinforced matrix alloy but highest } \\
\text { results are obtained at the largest } \\
\text { percentage of } \mathrm{TiB}_{2} \text { reinforced } \\
\text { composite. }\end{array}$ & {$[46]$} \\
\hline 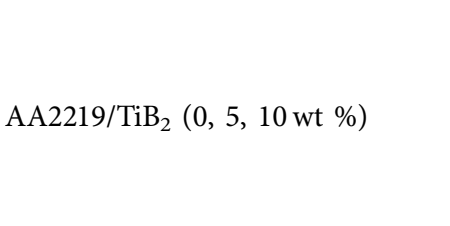 & $\begin{array}{l}\text { In situ reaction } \\
\text { process }\end{array}$ & $\begin{array}{l}\text { UTS, yield strength, } \\
\text { ductility }\end{array}$ & $\begin{array}{l}\text { Tensile and yield strength were greater } \\
\text { than those of parent alloy and they } \\
\text { raised with the raise in reinforcement, } \\
\text { in all composites. Incorporation of } \mathrm{TiB}_{2} \\
\text { reduced the elongation of the pure } \mathrm{Al} \\
\text { matrix. }\end{array}$ & {$[47]$} \\
\hline $\mathrm{LM} 25 / \mathrm{TiB}_{2}(0,2.5,5,7.5)$ & Mixed salt method & $\begin{array}{l}\text { UTS, yield strength, } \% \\
\text { elongation }\end{array}$ & $\begin{array}{l}\text { UTS and yield strength were superior to } \\
\text { those of base aluminum and they were } \\
\text { enriched with the augmented mass } \\
\text { proportion of reinforcement while the } \\
\text { mechanical characteristics of the } \\
\text { composite increases owing to the } \\
\text { presence of } \mathrm{TiB}_{2} \text { filler materials. }\end{array}$ & {$[48]$} \\
\hline $\begin{array}{l}\mathrm{Al} / \mathrm{TiB}_{2}(0,1.5,2.5,3.5,5 \text { and } 10 \mathrm{wt} \\
\left.\% \mathrm{TiB}_{2}\right)\end{array}$ & Powder metallurgy & Compressive strength & $\begin{array}{c}\text { Mechanical property was greater than } \\
\text { that of basic alloy. }\end{array}$ & [49] \\
\hline $\begin{array}{l}\mathrm{A} 356 / \mathrm{TiB}_{2}(0,0.5,1.5,3 \text {, and } 5 \mathrm{vol} \\
\%)\end{array}$ & Stir casting & Hardness & $\begin{array}{l}\text { Use of hard } \mathrm{TiB}_{2} \text { has a remarkable effect } \\
\text { in increasing microhardness and UTS } \\
\text { of the } \mathrm{Al} \text { composite. }\end{array}$ & {$[50]$} \\
\hline $\mathrm{A}_{356} / \mathrm{TiB}_{2}(0,3,5.6,7.8 \mathrm{vol} \%)$ & In situ casting & $\begin{array}{l}\text { UTS, yield strength, } \\
\text { and fracture toughness }\end{array}$ & $\begin{array}{l}\text { The produced composite with } 7.8 \text { vol\% } \\
\mathrm{TiB}_{2} \text { shows the greatest improvement in } \\
\text { mechanical performance when } \\
\text { compared to the base metal. }\end{array}$ & {$[51]$} \\
\hline $\mathrm{AA} 6061 / \mathrm{TiB}_{2}(0,5,7 \mathrm{wt} \%)$ & In situ casting & $\begin{array}{l}\text { Microhardness, UTS, } \\
\text { elongation }\end{array}$ & $\begin{array}{l}\text { In all the composites microhardness } \\
\text { and UTS were greater than those of } \\
\text { unreinforced base matrix and they } \\
\text { increased with increase in } \\
\text { reinforcement content. The addition of } \\
\mathrm{TiB}_{2} \text { particulates to the AA6061 matrix } \\
\text { has led to reduced ductility of the AMC. }\end{array}$ & {$[52]$} \\
\hline $\mathrm{AA} 7075 / \mathrm{TiB}_{2}(0,5,10 \mathrm{wt} \%)$ & $\begin{array}{l}\text { In situ casting (mixing } \\
\text { salt route) }\end{array}$ & Bending strength & $\begin{array}{c}\text { Bending characteristics are enhanced } \\
\text { with the increased content of filler } \\
\text { materials. }\end{array}$ & {$[53]$} \\
\hline AA6061- $\mathrm{TiB}_{2}(0,3,6,9 \mathrm{wt} \%)$ & $\begin{array}{l}\text { In situ reaction } \\
\text { process }\end{array}$ & Microhardness (HV) & $\begin{array}{l}\text { Microhardness of the experimental } \\
\text { AMCs was greater than that of plain } \\
\text { alloy but highest results are achieved at } \\
\text { the superior percentage of } \mathrm{TiB}_{2} \\
\text { reinforced composite. }\end{array}$ & {$[54]$} \\
\hline $\begin{array}{l}\mathrm{AA} 1100-\mathrm{TiB}_{2}(0, \mathrm{Al} 4.5 \% \mathrm{Cu}-15 \mathrm{vol} \\
\% \mathrm{TiB}_{2}, \mathrm{Al} 4.5 \% \mathrm{Cu} 3 \% \mathrm{C}-15 \mathrm{vol} \% \\
\left.\mathrm{TiB}_{2}\right)\end{array}$ & In situ method & $\begin{array}{l}\text { Tensile strength, } \\
\text { elongation }\end{array}$ & $\begin{array}{l}\text { Tensile strength of the composite was } \\
\text { greater than that of unreinforced plain } \\
\text { alloy and all these characteristics were } \\
\text { enriched when augmented amount of } \\
\text { filler content is found. Addition of } \mathrm{TiB}_{2} \\
\text { reduced the ductility of the matrix alloy. }\end{array}$ & {$[55]$} \\
\hline $\begin{array}{l}\text { Commercial pure }(\mathrm{CP}) \mathrm{Al}-\mathrm{TiB}_{2}(0, \\
5,10,15,20 \text { vol } \%)\end{array}$ & Powder metallurgy & UTS, yield strength & $\begin{array}{l}\text { UTS and yield strength were superior to } \\
\text { those of base alloy in both processes and } \\
\text { were enhanced with increase in filler } \\
\text { material, in all composites. }\end{array}$ & [56] \\
\hline $\mathrm{LM} 25-\mathrm{TiB}_{2}(0,2.5,5,7.5 \mathrm{wt} \%)$ & In situ method & $\begin{array}{l}\text { Brinell hardness, UTS, } \\
\text { yield strength, } \\
\text { elongation }\end{array}$ & $\begin{array}{l}\text { The improved hardness and the } \\
\text { reduction in the ductility of } \mathrm{LM}_{2} 5-\mathrm{TiB}_{2} \\
\text { AMCs are observed when } \mathrm{TiB}_{2} \text { content } \\
\text { is increased in the AMCs. }\end{array}$ & {$[57]$} \\
\hline
\end{tabular}


TABle 2: Continued.

\begin{tabular}{|c|c|c|c|c|}
\hline MMC within (wt \%) & $\begin{array}{l}\text { Manufacturing } \\
\text { process }\end{array}$ & Mechanical properties & Remarks & Reference \\
\hline $\begin{array}{l}\mathrm{Al}-4 \mathrm{Cu}-\mathrm{TiB}_{2}(0,2.5,5,7.5,10 \mathrm{wt} \\
\%)\end{array}$ & In situ method & Hardness (HV) & $\begin{array}{l}\text { The microhardness of the fabricated } \\
\text { composite tends to augment with the } \\
\text { rise in } \mathrm{TiB}_{2} \text { content. }\end{array}$ & {$[58]$} \\
\hline $\begin{array}{l}\mathrm{Al}-2.5 \% \mathrm{TiB}_{2}(25 \%, 120 \%, 140 \% \\
\mathrm{KBF}_{4} \text { excess than stoichiometry) } \\
2.5 \% \mathrm{TiB}_{2}\end{array}$ & In situ method & Microhardness (HV) & $\begin{array}{c}\text { Microhardness of the AMCs increased } \\
\text { as compared to nonreinforced alloy } \\
\text { matrix. }\end{array}$ & [59] \\
\hline 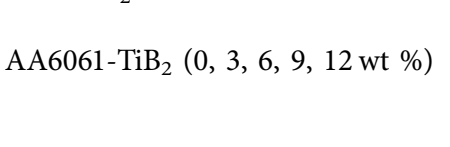 & Stir casting & $\begin{array}{l}\text { Hardness, UTS, yield } \\
\text { strength, }\end{array}$ & $\begin{array}{l}\text { Yield strength, hardness, and tensile } \\
\text { strength were superior to those of } \\
\text { nonreinforced base matrix alloy. } \\
\text { Both the tensile strength and the }\end{array}$ & {$[60]$} \\
\hline $\begin{array}{l}\text { AA6061-TiB } 2(0,2,4,6,8,10,12 \mathrm{wt} \\
\%)\end{array}$ & $\begin{array}{l}\text { In situ and equal } \\
\text { channel angular } \\
\text { pressing (ECAP) }\end{array}$ & $\begin{array}{l}\text { Hardness, UTS, } \\
\text { elongation, }\end{array}$ & $\begin{array}{l}\text { hardness were enhanced as compared } \\
\text { to pure plain matrix alloy. The } \\
\text { elongation of the AMCs was found to } \\
\text { be somewhat lower than that of the base } \\
\text { alloy. }\end{array}$ & {$[61]$} \\
\hline $\begin{array}{l}\mathrm{Al}-\mathrm{B}_{4} \mathrm{C}-\mathrm{TiB}_{2}(10,20,30,40 \mathrm{wt} \% \\
\left.\mathrm{TiB}_{2}\right)\end{array}$ & Vacuum infiltration & $\begin{array}{l}\text { Hardness (HRA) and } \\
\text { flexural strength }\end{array}$ & $\begin{array}{l}\text { The hardness and flexural strength of } \\
\text { the specimens tend to decrease during } \\
\text { the increment of the reinforcement } \\
\text { content. }\end{array}$ & {$[62]$} \\
\hline $\begin{array}{l}\text { AA6061, AA6061-5 wt\% } \mathrm{TiB}_{2} \\
\text { AA7015, AA7015-5 wt\% } \mathrm{TiB}_{2}\end{array}$ & Hot extrusion & Hardness & $\begin{array}{l}\text { Hardness of the AMCs was superior to } \\
\text { that of plain alloy and it is enhanced } \\
\text { with the rising content of hard } \mathrm{TiB}_{2} \\
\text { reinforcement. }\end{array}$ & {$[63]$} \\
\hline $\begin{array}{l}\text { AA6061, AA6061-10\% SiC- } 2.5 \% \\
\mathrm{TiB}_{2}, 5 \% \mathrm{TiB}_{2}\end{array}$ & Stir casting & Hardness (HV) & $\begin{array}{c}\text { Hardness of the } \mathrm{Al}-10 \% \mathrm{SiC}-2.5 \% \mathrm{TiB}_{2} \\
\text { AMCs increased as compared to basic } \\
\text { alloy matrix. }\end{array}$ & {$[64]$} \\
\hline $\mathrm{Al} 6061-\mathrm{TiB}_{2}(0,6,8,10)$ & In situ casting route & $\begin{array}{l}\text { Hardness, UTS, } \\
\text { elongation }\end{array}$ & $\begin{array}{l}\text { Hardness and UTS of the prepared } \\
\text { AMCs were enriched linearly as } \mathrm{TiB}_{2} \\
\text { content increased. The incorporation of } \\
\text { hard } \mathrm{TiB}_{2} \text { filler materials into the } \\
\text { AA6061 matrix has led to diminished } \\
\text { elongation of the AMC. }\end{array}$ & {$[65]$} \\
\hline $\begin{array}{l}\text { Commercial pure aluminium } \\
(\mathrm{CP})-\mathrm{TiB}_{2}\left(0,2.5,5 \mathrm{wt} \% \mathrm{TiB}_{2}\right)\end{array}$ & In situ casting process & Hardness, UTS & $\begin{array}{l}\text { Hardness, fracture, and tensile strength } \\
\text { improved with enhanced titanium } \\
\text { diboride particle content. }\end{array}$ & {$[66]$} \\
\hline AA7178-0, 3, 6, 9 wt\% $\left.\mathrm{TiB}_{2}\right)$ & In situ casting method & $\begin{array}{l}\text { Hardness, compression } \\
\text { strength, and tensile } \\
\text { strength }\end{array}$ & $\begin{array}{l}\text { Microhardness, compression, and } \\
\text { tensile strength are being improved } \\
\text { when the weight fraction of } \mathrm{TiB}_{2} \\
\text { particles reached up to } 9 \% \text {. }\end{array}$ & {$[67]$} \\
\hline $\begin{array}{l}\mathrm{A} 1100-\mathrm{TiB}_{2}, \mathrm{AlCu} \mathrm{TiB}_{2}(15 \mathrm{Vf} \% \\
\left.\mathrm{TiB}_{2}\right)\end{array}$ & $\begin{array}{l}\text { Exothermic reaction } \\
\text { process }\end{array}$ & UTS, yield strength & $\begin{array}{l}\text { Mechanical properties of the AMMCs } \\
\text { increased as compared to unreinforced } \\
\text { plain matrix alloy. }\end{array}$ & {$[68]$} \\
\hline $\mathrm{Al}-7 \mathrm{Si} / \mathrm{TiB}_{2}\left(0,5,10 \mathrm{wt} \% \mathrm{TiB}_{2}\right)$ & In situ & $\begin{array}{l}\text { Hardness, UTS, yield } \\
\text { strength }\end{array}$ & $\begin{array}{c}\text { Maximum hardness, yield, and tensile } \\
\text { strength of the AMCs are obtained } \\
\text { where the } \mathrm{TiB}_{2} \text { filler material reached } \\
10 \% .\end{array}$ & [69] \\
\hline $\begin{array}{l}\mathrm{Al}-4 \% \mathrm{Cu}-\mathrm{TiB}_{2} \text { (chemical reaction } \\
\text { time-15, 25, } 35 \mathrm{~min})\end{array}$ & In situ casting & $\begin{array}{l}\text { Hardness, UTS, yield } \\
\text { strength, elongation }\end{array}$ & $\begin{array}{l}\text { Mechanical properties of the developed } \\
\text { aluminum matrix AMCs were superior } \\
\text { to those of unreinforced matrix. }\end{array}$ & {$[70]$} \\
\hline $\begin{array}{l}\mathrm{A} 356-\mathrm{TiB}_{2}(0,0.5,1.5,3.5 \text {-micron } \\
\left.\text { and nano } \mathrm{TiB}_{2}\right)(\text { casting } \\
\left.\text { temperature } 750,800,900^{\circ} \mathrm{C}\right)\end{array}$ & Melt stirring casting & UTS and yield strength & $\begin{array}{l}\text { Yield and tensile strength were } \\
\text { augmented compared to those of basic } \\
\text { alloy. A356-1.5 } \mathrm{wt} \% \mathrm{TiB}_{2}-900^{\circ} \mathrm{C} \text { AMC } \\
\text { exhibits higher mechanical properties. }\end{array}$ & {$[71]$} \\
\hline $\begin{array}{l}\mathrm{AA} 6061 / \mathrm{TiB}_{2} / \mathrm{Gr} 0 \%, 5 \%, 10 \%, \\
20 \% \mathrm{TiB}_{2}+2 \% \mathrm{Gr}, 5 \%, 10 \%, 20 \% \\
\mathrm{TiB}_{2}\end{array}$ & Melt stirring method & UTS and hardness & $\begin{array}{l}\text { UTS and hardness of the AMCs were } \\
\text { augmented compared to those of base } \\
\text { alloy and were then boosted with the } \\
\text { augmented content of filler material. }\end{array}$ & {$[72]$} \\
\hline
\end{tabular}


TABle 2: Continued.

\begin{tabular}{|c|c|c|c|c|}
\hline MMC within (wt \%) & $\begin{array}{l}\text { Manufacturing } \\
\text { process }\end{array}$ & Mechanical properties & Remarks & Reference \\
\hline $\mathrm{AA} 6063 / \mathrm{TiB}_{2}(0,5,10)$ & In situ & Hardness (HV) & $\begin{array}{l}\text { Bulk hardness of the composite was } \\
\text { superior to that of base alloy and it was } \\
\text { enriched with the increasing content of } \\
\text { filler material. }\end{array}$ & {$[73]$} \\
\hline Al6063- $\mathrm{TiB}_{2}(2.8,6.7,10 \mathrm{wt} \%)$ & In situ & Microhardness (HV) & $\begin{array}{l}\text { Microhardness was } 27.25 \% \text { times } \\
\text { superior to that of base aluminum while } \\
\text { hardness increased with increased } \\
\text { content of reinforcement. }\end{array}$ & {$[74]$} \\
\hline $\begin{array}{l}\mathrm{A} 356-\mathrm{TiB}_{2}\left(2,3,4,5,6 \mathrm{wt} \% \mathrm{TiB}_{2}\right) \\
\text { reaction time }(20,25,30,35, \\
40 \mathrm{~min}) \text { temperature }(800,850,\end{array}$ & In situ & Hardness (HV), UTS & $\begin{array}{l}\text { Use of } \mathrm{TiB}_{2} \text { has a significant influence in } \\
\text { enriching the hardness and tensile } \\
\text { strength of the AMCs. }\end{array}$ & {$[75]$} \\
\hline $\begin{array}{l}\text { AA6061-10\%SiC- }(0,2.5,5 \text { wt \% } \\
\left.\text { TiB }_{2}\right)\end{array}$ & Stir casting & $\begin{array}{l}\text { Hardness, tensile } \\
\text { strength }\end{array}$ & $\begin{array}{l}\text { Higher hardness was achieved at the } \\
\text { percentage of } \mathrm{Al}-10 \% \mathrm{SiC}-2.5 \mathrm{TiB}_{2} \mathrm{AMC} \\
\text { and maximum tensile strength obtained } \\
\text { at the percentage of } \mathrm{Al}-10 \% \mathrm{SiC}-0 \% \mathrm{TiB}_{2} \\
\text { AMC. }\end{array}$ & {$[76]$} \\
\hline $\begin{array}{l}\text { AA6061-5\%, 10\% } \mathrm{TiB}_{2}-1,2,3,4 \% \\
\text { Gr }\end{array}$ & Stir casting & $\begin{array}{l}\text { Hardness, compressive } \\
\text { strength, tensile } \\
\text { strength }\end{array}$ & $\begin{array}{l}\text { Hardness and UTS of the aluminum } \\
\text { composites were superior to those of } \\
\text { parent matrix alloy and it is enriched by } \\
\text { the increasing content of } 10 \mathrm{wt} \% \mathrm{TiB}_{2} \\
\text { and } 2 \mathrm{wt} \% \mathrm{Gr} \text {. }\end{array}$ & {$[77]$} \\
\hline $\begin{array}{l}\mathrm{Al} 2014-\mathrm{TiB}_{2}\left(0,5 \mathrm{wt} \% \mathrm{TiB}_{2}(5 \mathrm{wt} \%\right. \\
\left.\mathrm{TiB}_{2}+0.5 \% \mathrm{CeO}_{2}\right)\end{array}$ & In situ casting & $\begin{array}{l}\text { Hardness, tensile } \\
\text { strength, yield strength }\end{array}$ & $\begin{array}{l}\text { Hardness, yield, and tensile strength } \\
\text { were superior to those of base alloy and } \\
\text { they were enriched by augmenting the } \\
\text { amount of filler content }\left(\mathrm{TiB}_{2}+\mathrm{CeO}_{2}\right) \text {. }\end{array}$ & {$[78]$} \\
\hline $\mathrm{AA} 2219-\mathrm{TiB}_{2} / \mathrm{ZrB}_{2}(0,3,6 \%)$ & In situ casting & Microhardness (HV) & $\begin{array}{l}\text { Microhardness of the composite was } \\
\text { superior to that of basic alloy. }\end{array}$ & {$[79]$} \\
\hline $\begin{array}{l}\text { Commercial pure aluminum (CP)- } \\
\mathrm{TiB}_{2}\left(0,5 \text { vol } \% \mathrm{TiB}_{2}, 5 \text { vol } \%\right. \\
\left.\mathrm{TiB}_{2}+0.5 \text { wt } \% \mathrm{CeO}_{2}\right)\end{array}$ & In situ casting & $\begin{array}{l}\text { UTS, YS, elastic } \\
\text { modulus }\end{array}$ & $\begin{array}{l}\text { Mechanical properties of the } \\
\text { experimental composites were superior } \\
\text { to those of parent matrix alloy. }\end{array}$ & {$[80]$} \\
\hline $\begin{array}{l}\mathrm{A} 356-\mathrm{TiB}_{2}(0,2.5,5,7.5,10 \%) \mathrm{At} \\
\text { T6 treated }\end{array}$ & In situ composite & Vickers hardness (HV) & $\begin{array}{c}\text { Microhardness was improved as } \\
\text { compared to pure base matrix } \\
\text { aluminum alloy. }\end{array}$ & {$[81]$} \\
\hline Al-4 wt $\left.\% \mathrm{Cu}-5,10,15,20 \% \mathrm{TiB}_{2}\right)$ & $\begin{array}{l}\text { Hot isostatic } \\
\text { processing }\end{array}$ & $\begin{array}{l}\text { Hardness, yield } \\
\text { strength, UTS }\end{array}$ & $\begin{array}{l}\text { All these properties of the composite } \\
\text { were superior to those of base material. }\end{array}$ & {$[82]$} \\
\hline $\begin{array}{l}\mathrm{Al} 6061-\mathrm{TiB}_{2}(10,11,12,13,14 \mathrm{wt} \% \\
\left.\mathrm{TiB}_{2}\right)\end{array}$ & In situ casting process & Hardness, UTS & $\begin{array}{l}\text { Peak UTS and hardness of the produced } \\
\text { AMCs are obtained where the } \mathrm{TiB}_{2} \\
\text { content reached } 14 \% \text {. }\end{array}$ & {$[83]$} \\
\hline $\mathrm{A} 356-\mathrm{TiB}_{2}(0,2.5,5,7.5,10 \mathrm{wt} \%)$ & $\begin{array}{l}\text { Salt metal reaction } \\
\text { process }\end{array}$ & $\begin{array}{l}\text { Hardness, UTS, \% } \\
\text { elongation }\end{array}$ & $\begin{array}{l}\text { Mechanical behaviors of the produced } \\
\text { aluminum-based metal matrix } \\
\text { composites were superior to those of } \\
\text { nonreinforced alloy. }\end{array}$ & {$[84]$} \\
\hline AA7075-TiB $2\left(0,9 w t \% \mathrm{TiB}_{2}\right)$ & In situ method & $\begin{array}{l}\text { Microhardness and } \\
\text { tensile strength }\end{array}$ & $\begin{array}{l}\text { UTS and hardness of the AA7075-9 wt } \\
\% \text { titanium boride AMCs increased as } \\
\text { compared to nonreinforced alloy } \\
\text { matrix. }\end{array}$ & {$[85]$} \\
\hline $\begin{array}{l}\mathrm{AA} 2009-\mathrm{TiB}_{2}\left(8 \mathrm{wt} \% \mathrm{TiB}_{2}\right) \\
\text { solution temperature }(498,508, \\
\left.520,530^{\circ} \mathrm{C}\right)\end{array}$ & $\begin{array}{l}\text { Exothermic reaction } \\
\text { process }\end{array}$ & Hardness and UTS & $\begin{array}{l}\text { The manufactured AMCs reveal the } \\
\text { maximum hardness after solution was } \\
\text { treated at } 530^{\circ} \mathrm{C} \text { and the superior tensile } \\
\text { strength after solution was treated at } \\
520^{\circ} \mathrm{C} \text {. }\end{array}$ & {$[86]$} \\
\hline $\mathrm{AA} 2024-\mathrm{TiB}_{2}\left(0,7 \mathrm{wt} \% \mathrm{TiB}_{2}\right)$ & Stir casting & Microhardness & $\begin{array}{l}\text { Microhardness of the developed } \\
\text { composite was higher than that of } \\
\text { unreinforced monolithic alloy. }\end{array}$ & {$[87]$} \\
\hline
\end{tabular}


TABle 2: Continued.

\begin{tabular}{lccc}
\hline MMC within (wt \%) & $\begin{array}{c}\text { Manufacturing } \\
\text { process }\end{array}$ & Mechanical properties & Remarks \\
\hline AA7075- $\mathrm{TiB}_{2}\left(0,6,9,12 \mathrm{wt} \% \mathrm{TiB}_{2}\right)$ & In situ method & $\begin{array}{c}\text { Microhardness and } \\
\text { tensile strength }\end{array}$ & $\begin{array}{c}\text { Mechanical properties of the } \\
\text { manufactured composites were } \\
\text { superior to those of monolithic alloy. } \\
\text { Superior UTS and hardness of the } \\
\text { proposed AMCs is achieved where the } \\
\text { TiB } \text { C }_{2} \text { content reached } 12 \% .\end{array}$ \\
\hline
\end{tabular}

TABLE 3: Superior mechanical properties of titanium diboride based aluminum matrix composites.

\begin{tabular}{|c|c|c|c|c|c|c|}
\hline MMCs & Manufacturing process & $\begin{array}{l}\text { Macrohardness } \\
(\mathrm{BHN})\end{array}$ & $\begin{array}{c}\text { Microhardness } \\
(\mathrm{HV})\end{array}$ & $\begin{array}{l}\text { UTS } \\
(\mathrm{MPa})\end{array}$ & $\begin{array}{c}\text { YS } \\
(\mathrm{MPa})\end{array}$ & Reference \\
\hline $\mathrm{AA} 7050 / 6 \mathrm{wt} \% \mathrm{TiB}_{2}$ & $\begin{array}{l}\text { In situ casting } \\
\text { technique }\end{array}$ & - & - & 746 & 701 & {$[25]$} \\
\hline AA6061/12 wt $\% \mathrm{TiB}_{2}$ & $\begin{array}{l}\text { Exothermic reaction } \\
\text { process }\end{array}$ & 88.6 & - & 173.6 & 94.2 & {$[34]$} \\
\hline $\mathrm{Al} / 7 \mathrm{wt} \% \mathrm{TiB}_{2}$ & $\begin{array}{l}\text { Salt-metal reaction } \\
\text { route }\end{array}$ & 30 & - & 136.6 & - & {$[35]$} \\
\hline A356/8.37 vol\% $\mathrm{TiB}_{2}$ & In situ reaction process & - & - & 258.5 & 217.6 & {$[36]$} \\
\hline AA2219/10 wt $\% \mathrm{TiB}_{2}$ & $\begin{array}{l}\text { In situ casting } \\
\text { technique }\end{array}$ & - & 96 & 234 & 205 & {$[37]$} \\
\hline AA6063/13.12 wt $\% \mathrm{TiB}_{2}$ & In situ casting & - & 59.25 & 140.9 & - & {$[38]$} \\
\hline AA6061/10 wt $\% \mathrm{TiB}_{2}$ & High energy stir casting & - & 73.93 & 171 & - & [39] \\
\hline AA7075/9 wt $\% \mathrm{TiB}_{2}$ & In situ method & - & 128 & 285 & - & {$[40,85]$} \\
\hline AA6063/10 wt $\% \mathrm{TiB}_{2}$ & In situ casting route & - & 110 & - & - & {$[41,73]$} \\
\hline $\mathrm{A} 356 / 12.5 \mathrm{wt} \% \mathrm{TiB}_{2}$ & $\begin{array}{c}\text { Exothermic reaction } \\
\text { process }\end{array}$ & - & - & 382 & 324 & {$[42]$} \\
\hline $\mathrm{AA} 6061 / 12 \mathrm{wt} \% \mathrm{TiB}_{2}$ & Stir casting & - & 72.46 & 137.86 & - & {$[43]$} \\
\hline Al- $6 \mathrm{Cu}-0.2 \mathrm{Mg}-1 \mathrm{Mn} / 5 \mathrm{wt} \% \mathrm{TiB}_{2}$ & In situ casting & - & 84 & - & - & {$[44]$} \\
\hline AA6061/10 wt $\% \mathrm{TiB}_{2}$ & Melt stirring process & - & 58 & 195 & - & {$[45]$} \\
\hline AA2219/10 wt $\% \mathrm{TiB}_{2}$ & In situ reaction method & - & - & 426.97 & 301.75 & {$[47]$} \\
\hline $\mathrm{LM} / 7.5 \mathrm{wt} \% \mathrm{TiB}_{2}$ & Mixed salts method & - & - & 202 & 164 & {$[48]$} \\
\hline $\mathrm{A} 356 / 0.5 \mathrm{wt} \% \mathrm{TiB}_{2}$ & Stir casting & - & 118 & - & - & {$[50]$} \\
\hline AA $356 / 7.8$ vol\% $\mathrm{TiB}_{2}$ & In situ casting & - & - & 382 & 328 & {$[51]$} \\
\hline $\mathrm{AA} 6061 / 7 \mathrm{wt} \% \mathrm{TiB}_{2}$ & Mixed salt route & - & 47 & 145 & - & {$[52]$} \\
\hline AA6061/9 wt $\% \mathrm{TiB}_{2}$ & $\begin{array}{c}\text { Exothermic reaction } \\
\text { process }\end{array}$ & - & 123 & - & - & {$[54]$} \\
\hline $\mathrm{Al}-4.5 \% \mathrm{Cu}-3 \% \mathrm{C} / 15$ vol $\% \mathrm{TiB}_{2}$ & In situ method & - & - & 257.6 & - & {$[55]$} \\
\hline $\mathrm{Al}(\mathrm{CP}) / 20$ vol\% $\mathrm{TiB}_{2}$ & Powder metallurgy & -- & - & 191 & 115 & {$[56]$} \\
\hline $\mathrm{LM} 25 / 7.5 \mathrm{wt} \% \mathrm{TiB}_{2}$ & In situ reaction casting & 81 & - & 202 & 164 & {$[57]$} \\
\hline $\mathrm{Al}-4 \mathrm{Cu} / 10 \mathrm{wt} \% \mathrm{TiB}_{2}$ & $\begin{array}{l}\text { Liquid state in situ } \\
\text { casting }\end{array}$ & - & 138 & - & - & {$[58]$} \\
\hline AA6061/12 wt $\% \mathrm{TiB}_{2}$ & Stir casting & - & 77.93 & 140 & - & {$[60]$} \\
\hline $\mathrm{AA} 6061 / 2.5 \mathrm{wt} \% \mathrm{TiB}_{2} / 10 \% \mathrm{SiC}$ & Liquid state stir casting & - & 71.46 & - & - & {$[64]$} \\
\hline $\mathrm{AA} 6061 / 10 \mathrm{wt} \% \mathrm{TiB}_{2}$ & In situ method & - & 74.83 & 165.74 & - & {$[65]$} \\
\hline $\mathrm{Al}(\mathrm{CP}) / \mathrm{wt} \% \mathrm{TiB}_{2}$ & In situ method & - & - & 180 & 96 & {$[66]$} \\
\hline AA7178/9 wt $\% \mathrm{TiB}_{2}$ & In situ casting route & - & 94 & 211 & - & {$[67]$} \\
\hline $\mathrm{Al}-7 \mathrm{Si} / 13.12 \mathrm{wt} \% \mathrm{TiB}_{2}$ & In situ reaction process & - & 102 & 209 & 152 & {$[69]$} \\
\hline $\mathrm{AA} 6061 / 20 \mathrm{wt} \% \mathrm{TiB}_{2} / 2 \mathrm{Gr}$ & Stir casting route & - & 91.4 & 170 & - & {$[72]$} \\
\hline AA6061/2.5 wt $\% \mathrm{TiB}_{2} / 10 \mathrm{wt} \% \mathrm{SiC}$ & Stir casting & - & 75 & - & - & {$[76]$} \\
\hline $\mathrm{AA} 6061 / 10 \mathrm{wt} \% \mathrm{TiB}_{2} / 2 \mathrm{wt} \% \mathrm{gr}$ & Stir casting & - & 79.04 & - & - & {$[77]$} \\
\hline $\mathrm{AA} 2219-6 \mathrm{wt} \% \mathrm{TiB}_{2} / \mathrm{ZrB}_{2}$ & In situ casting & - & 155.6 & - & - & [79] \\
\hline $\mathrm{A} 356 / 2.5 \mathrm{wt} \% \mathrm{TiB}_{2}$ & In situ technique & - & 92 & - & - & {$[81,84]$} \\
\hline AA6061/14 wt $\% \mathrm{TiB}_{2}$ & In situ technique & - & 128 & 334 & - & [83] \\
\hline $\begin{array}{l}\mathrm{AA} 2009 / 8 \mathrm{wt} \% \mathrm{TiB}_{2} \text { (solution } \\
\text { temperature } 520^{\circ} \mathrm{C} \text { ) }\end{array}$ & In situ method & - & - & 538 & 364 & {$[86]$} \\
\hline AA2024/7 wt $\% \mathrm{TiB}_{2}$ & Stir casting & - & 116 & - & - & {$[87]$} \\
\hline AA7075/12 wt $\% \mathrm{TiB}_{2}$ & In situ technique & - & 141 & 287.95 & - & [88] \\
\hline
\end{tabular}




\section{Conclusions}

This review article examines the impact of titanium diboride $\left(\mathrm{TiB}_{2}\right)$ on aluminum matrix composites (AMCs). As seen in the previous section, various authors have discussed the mechanical properties of fabricated $\mathrm{Al} / \mathrm{TiB}_{2}$ composites, such as hardness, tensile strength, compressive strength, and yield strength. It shall be opined that the stir casting technique is the rare one in making $\mathrm{Al}-\mathrm{TiB}_{2}$ composite, whereas the in situ technique is the often-used technique due to its formation of more uniform $\mathrm{TiB}_{2}$ particles in the matrix. The $\mathrm{TiB}_{2}$ particles involved composites have rarely utilized squeeze casting, centrifugal casting, stir casting, and compocasting. Al alloys containing $\mathrm{TiB}_{2}$ reinforcements are to reveal enriched mechanical properties compared to monolithic alloys. Reported works also indicate the linearly augmented mechanical properties with the incorporation of $\mathrm{TiB}_{2}$. Several research works recommended that tensile strength and hardness of the AMCs were enriched with the inclusion of a rise in mass fraction of $\mathrm{TiB}_{2}$ particle contents.

\section{Data Availability}

The data used to support the findings of this study are included within the article.

\section{Conflicts of Interest}

The authors declare that there are no conflicts of interest regarding the publication of this article.

\section{References}

[1] L. Li, Z. Han, M. Gao et al., "Microstructures, mechanical properties, and aging behavior of hybrid-sized $\mathrm{TiB}_{2}$ particulate-reinforced 2219 aluminum matrix composites," Materials Science and Engineering: A, vol. 829, Article ID 142180, 2022.

[2] N. Saravanan, V. Yamunadevi, V. Mohanavel et al., "Effects of the interfacial bonding behavior on the mechanical properties of E-glass fiber/nanographite reinforced hybrid composites," Advances in Polymer Technology, vol. 2021, Article ID 6651896, 9 pages, 2021.

[3] V. Mohanavel, K. S. Ashraff Ali, S. Prasath, T. Sathish, and M. Ravichandran, "Microstructural and tribologi- cal characteristics of AA6351/ $\mathrm{Si}_{3} \mathrm{~N}_{4}$ composites manufactured by stir casting," Journal of Materials Research and Technology, vol. 9, no. 6, pp. 14662-14672, 2020.

[4] H. Abdizadeh and M. A. Baghchesara, "Investigation on mechanical properties and frac- ture behavior of A356 aluminum alloy based $\mathrm{ZrO}_{2}$ particle reinforced metal-matrix composites," Ceramics International, vol. 39, no. 2, pp. 2045-2050, 2013.

[5] D. Dey, A. Bhowmik, and A. Biswas, "Influence of $\mathrm{TiB}_{2}$ addition on friction and wear behavior of $\mathrm{Al} 2024-\mathrm{TiB}_{2}$ ex-situ composites," Trans Nonferrous Met Soc China, vol. 31, pp. 1249-1261, 2021.

[6] H. Wang, H. Zhang, Z. Cui, Z. Chen, and D. Chen, "Compressive response and microstructural evolution of in-situ $\mathrm{TiB}_{2}$ particle-reinforced 7075 aluminum matrix composites," Trans Nonferrous Met Soc China, vol. 31, pp. 1235-1248, 2021.
[7] A. Mohan Kumar, R. Rajasekar, P. Manoj Kumar, R. Parameshwaran, A. Karthick, and M. Muhibbullah, "Comparative analysis of drilling behaviour of synthetic and natural fiber-based composites," Advances in Materials Science and Engineering, vol. 2021, Article ID 9019334, 13 pages, 2021.

[8] P. Gurusamy, T. Sathish, V. Mohanavel et al., "Finite element analysis of temperature distribution and stress behavior of squeeze pressure composites," Advances in Materials Science and Engineering, vol. 2021, Article ID 8665674, 9 pages, 2021.

[9] R. Liu, W. Wang, H. Chen, and S. Wan, "Comparative study of recrystallization behavior and nanoindentation prop- erties of micro-/nano-bimodal size B4C particle-reinforced aluminium matrix composites under T6 and elec- tropulsing treatment," Journal of Alloys and Compounds, vol. 788, pp. 1056-1065, 2019.

[10] G. S. Guggari, S. Shivakumar, G. A. Manjunath et al., "Thermal and mechanical properties of vinyl ester hybrid composites with carbon black and glass reinforcement," Advances in Materials Science and Engineering, vol. 2021, Article ID 6030096, 7 pages, 2021.

[11] Z. Chen, T. Wang, Y. Zheng, and Y. Zhao, "Development of TiB2 reinforced aluminum foundry alloy based in situ composites - Part I: an improved halide salt route to fabricate Al-5wt\%TiB2 master composite," Mater Sci Eng A, vol. 605, pp. 301-309, 2014.

[12] L. Zhenglong, B. Jiang, C. Yanbin, C. Xi, T. Ze, and Q. Xikun, "Effect of $\mathrm{TiB}_{2}$ content on microstructural features and hardness of $\mathrm{TiB}_{2} / \mathrm{AA} 7075$ composites manufactured by LMD," Journal of Manufacturing Processes, vol. 53, pp. 283-292, 2020.

[13] T. Sathish, S. Tharmalingam, V. Mohanavel et al., "Weldability investigation and optimization of process variables for TIG-welded aluminium alloy (AA 8006)," Advances in Materials Science and Engineering, vol. 2021, Article ID 2816338, 17 pages, 2021.

[14] K. Tian, Y. Zhao, L. Jiao, and S. Zhang, "Effects of in situ generated $\mathrm{ZrB} 2$ nano-particles on microstructure and tensile properties of 2024Al matrix composites," Journal of Alloys and Compounds, vol. 594, pp. 1-6, 2014.

[15] S. Ray, "Review synthesis of cast metal matrix particulate composites," Journal of Materials Science, vol. 28, pp. 53975413, 1993.

[16] R. Taherzadeh Mousavian, S. R. Damadi, R. Azari Khosroshahi, D. Brabazon, and M. Mohammadpour, "A comparison study of applying metallic coating on SiC particles for manufacturing of cast aluminum matrix composites," International Journal of Advanced Manufacturing Technology, vol. 81, no. 1-4, pp. 433-444, 2015.

[17] U. Muthuraman, R. Shankar, V. K. Nassa et al., "Energy and economic analysis of curved, straight, and spiral flow flat-plate solar water collector," International Journal of Photoenergy, 2021.

[18] V. Mohanavel, K. Rajan, S. Suresh Kumar, A. Chockalingam, A. Roy, and T. Adithiyaa, "Synthesis, mechanical and tribological characterization of stir-cast Al-SiCp composites," Materials Today: Proceedings, vol. 5, no. 1, pp. 1740-1746, 2018.

[19] H. Zhu, Bo Hua, T. Cui, and J. Huang, "Microwave combustion synthesis of in situ $\mathrm{Al} 2 \mathrm{O} 3$ and $\mathrm{Al} 3 \mathrm{Zr}$ reinforced aluminum matrix composites," Materials Research Bulletin, vol. 68, pp. 283-288, 2015.

[20] Ö. Savas, and R. Kayikci, "Production and wear properties of metal matrix composites reinforced with boride particles," Materials \& Design, vol. 51, pp. 641-647, 2013. 
[21] V. Mohanavel, K. Rajan, S. Arul, and P. V. Senthil, "Production, Microstructure and Mechanical behavior of AA6351/ $\mathrm{TiB}_{2}$ composite synthesized by direct melt reaction method," Materials Today: Proceedings, vol. 4, no. 2, pp. 3315-3324, 2017.

[22] D. Dey, A. Bhowmik, and A. Biswas, "Charcaterization of Physical and mechanical properties of aluminium based composites reinforced with titanium diboride particulates," Journal of Composite Materials, vol. 55, no. 14, p. 2021, 1979-1991.

[23] D. Srinivasan, G. Veerappan, M. Ravichandran et al., "Investigation on electric erosion behavior of nickel-based super alloy (Waspaloy: $\mathrm{Ni}, \mathrm{Cr}, \mathrm{Co}, \mathrm{Mo}, \mathrm{Ti}, \mathrm{Al}$ ) using response surface methodology," Surface Topography: Metrology and Properties, vol. 9, no. 3, Article ID 035006, 2021.

[24] C. Mallikarjuna, S. M. Shashidhara, U. S. Mallik, and K. I. Parashivamurthy, "Grain refinement and wear properties evaluation of aluminum alloy 2014 matrix-TiB2 in-situ composites," Materials \& Design, vol. 32, no. 6, pp. 3554-3559, 2011.

[25] Y. Ma, Z. Chen, M. Wang, D. Chen, N. Ma, and H. Wang, "High cycle fatigue behavior of the in-situ TiB2/7050 composite," Mater Sci Eng A, vol. 640, pp. 350-356, 2015.

[26] S. M. Ma, P. Zhang, G. Ji et al., "Microstructure and mechanical properties of friction stir processed $\mathrm{Al}-\mathrm{Mg}-\mathrm{Si}$ alloys dispersion-strengthened by nanosized TiB2 particles," Journal of Alloys and Compounds, vol. 616, pp. 128-136, 2014.

[27] J. Lei, Y. Zhao, Y. Wu, D. Chen, and X. Wang, "Microstructures of in-situ TiB2/7055Al composites by the ultrasonic and magnetic coupled field," Rare Metal Materials and Engineering, vol. 43, no. 1, pp. 6-10, 2014.

[28] T. Hong, X. Li, H. Wang, D. Chen, and K. Wang, "Effects of TiB2 particles on aging behavior of in-situ TiB2/Al- $\mathrm{Cu}-\mathrm{Mg}$ composites," Mater Sci Eng A, vol. 624, pp. 110-117, 2015.

[29] K. Niranjan and P. R. Lakshminarayanan, "Dry sliding wear behaviour of in situ Al-TiB2 composites," Materials \& Design, vol. 47, pp. 167-173, 2013.

[30] S. L. Zhang, X. W. Dong, Y. T. Zhao et al., "Preparation and wear properties of TiB2/Al-30Si composites via in- situ melt reactions under high-energy ultrasonic field," Trans Nonferrous Met Soc China, vol. 24, pp. 3894-3900, 2014.

[31] H. B. Michael Rajan, S. Ramabalan, I. Dinaharan, and S. J. Vijay, "Effect of TiB2 content and temperature on sliding wear behavior of AA7075/TiB2 in situ aluminum cast composites," Archives of Civil and Mechanical Engineering, vol. 14, no. 1, pp. 72-79, 2014.

[32] J. Sun, X. Zhang, Y. Zhang, N. Ma, and H. Wang, "Effects of alloy element on the morphology transformation of TiB2 particles in Al matrix," Micron, vol. 70, pp. 21-25, 2015.

[33] C. S. Ramesh, S. Pramod, and R. Keshavamurthy, "A study on microstructure and mechanical properties of Al 6061-TiB2 in-situ composites," Materials Science and Engineering: A, vol. 528, no. 12, pp. 4125-4132, 2011.

[34] T. V. Christy, N. Murugan, and S. Kumar, "A comparative study on the microstructures and mechanical properties of Al6061 alloy and the MMC Al6061/TiB2/12p," Journal of Minerals and Materials Characterization and Engineering, vol. 9, pp. 57-65, 2010.

[35] F. Chen, Z. Chen, F. Mao, T. M. Wang, and Z. Cao, "TiB2 reinforced aluminum based In-situ composites fabricated by stir casting," Mater Sci Eng A, vol. 625, pp. 357-368, 2015.

[36] M. Wang, D. Chen, Z. Chen, Y. W. Feifei, W. Naiheng, and H. Wang, "Mechanical properties of In-situ TiB2/A356 composites," Mater Sci Eng A, vol. 590, pp. 246-254, 2014.
[37] N. R. Rajasekaran and V. Sampath, "Effect of in situ TiB2 particle addition on the mechanical properties of AA2219 Al alloy composite," Journal of Minerals and Materials Characterization and Engineering, vol. 10, pp. 527-534, 2011.

[38] C. S. Ramesh, A. Ahamed, B. H. Channabasappa, and R. Keshavamurthy, "Development of Al 6063-TiB2 in situ composites," Materials \& Design, vol. 31, no. 4, pp. 2230-2236, 2010.

[39] S. Suresh, N. Shenbaga Vinayaga Moorthi, S. C. Vettivel, and N. Selvakumar, "Mechanical behavior and wear prediction of stir cast Al-TiB2 composites using response surface methodology," Materials \& Design, vol. 59, pp. 383-396, 2014.

[40] H. B. Michael Rajan, S. Ramabalan, I. Dinaharan, and S. J. Vijay, "Synthesis and characterization of in situ formed titanium diboride particulate reinforced AA7075 aluminum alloy cast composites," Materials \& Design, vol. 44, pp. $438-445,2013$.

[41] S. Natarajan, R. Narayanasamy, S. P. Kumaresh Babu, G. Dinesh, B. Anil Kumar, and K. Sivaprasad, "Sliding wear behaviour of $\mathrm{Al} \mathrm{6063/TiB2}$ in situ composites at elevated temperatures," Materials \& Design, vol. 30, no. 7, pp. 2521-2531, 2009.

[42] F. Wang, J. Xu, J. Li, X. Li, and H. Wang, "Fatigue crack initiation and propagation in A356 alloy reinforced with Insitu TiB2 particles," Mater Des, vol. 33, pp. 236-241, 2012.

[43] S. Suresh and N. Shenbaga Vinayaga Moorthi, "Process development in stir casting and investigation on microstructures and wear behavior of TiB2 on Al6061 MMC," Procedia Engineering, vol. 64, pp. 1183-1190, 2013.

[44] F. Xie and Z. H. Xue, "Characterizing an in situ TiB2 particulates reinforced aluminium-based composite and its heat treatment," Physics Procedia, vol. 50, pp. 13-18, 2013.

[45] S. Johny James, K. Venkatesan, P. Kuppan, and R. Ramanujam, "Comparative study of composites reinforced with $\mathrm{SiC}$ and TiB2," Procedia Engineering, vol. 97, pp. 10121017, 2014.

[46] P. T. Li, Y. Li, Y. Wu, and Ma G. Liu, "Distribution of TiB2 particles and its effects on the mechanical properties of A390 alloy," Mater Sci Eng A, vol. 546, pp. 146-152, 2012.

[47] D. Chen, M. L. Wang, Y. J. Zhang, X. F. Li, Z. Chen, and N. H. Ma, "Microstructure and mechanical properties of TiB2/2219 composites," Materials Research Innovations, vol. 18, no. sup4, pp. 514-518, 2014.

[48] S. Madhavan and S. Balasivanandha Prabu, "Deformation behaviour and failure mechanisms of Al-TiB2in situcomposites," Materials Science and Technology, vol. 29, no. 3, pp. 268-272, 2013.

[49] P. Hosseini Vajargah, H. Abdizadeh, and M. A. Baghchesara, "Fabrication of TiB2 nanoparticulates-reinforced aluminum matrix composites by powder metallurgy route," Journal of Composite Materials, vol. 49, no. 25, pp. 3115-3125, 2015.

[50] M. Karbalaei Akbari, S. Rajabi, K. Shirvanimoghaddam, and H. R. Baharvandi, "Wear and friction behavior of nanosized TiB2 and TiO2 particle-reinforced casting A356 aluminum nanocomposites: a comparative study focusing on particle capture in matrix," Journal of Composite Materials, vol. 49, no. 29 , pp. 3665-3681, 2015.

[51] F. Wang, J. Li, J. Xu, X. Li, Y. Zhang, and H. Wang, "Investigation on fracture toughness of aluminum matrix composites reinforced with In-situ titanium diboride particles," Journal of Composite Materials, vol. 46, pp. 2145-2150, 2011.

[52] V. Auradi, S. L. Biradar, S. M. Suresha, and S. A. Kori, "Microstructure and mechanical characterization of $\mathrm{Al}-\mathrm{Tib}_{2}$ 
in situ metal matrix composites produced via master alloy route," Applied Mechanics and Materials, vol. 592-594, pp. 494-498, 2014.

[53] D. Chen, Z. Chen, P. Zhang et al., "Bending properties of AA7075 aluminium alloy reinforced with in-situ TiB2 particles," Advanced Materials Research, pp. 1005-1010, 2012.

[54] V. Anandakrishnan and A. Mahamani, "Investigations of flank wear, cutting force, and surface roughness in the machining of Al-6061-TiB2 in situ metal matrix composites produced by flux-assisted synthesis," International Journal of Advanced Manufacturing Technology, vol. 55, no. 1-4, pp. 65-73, 2011.

[55] K. L. Tee, L. Lü, and M. O. Lai, "Improvement in mechanical properties of in-situ Al-TiB2 composite by incorporation of carbon," Materials Science and Engineering: A, vol. 339, no. 12, pp. 227-231, 2003.

[56] S. C. Tjong and K. F. Tam, "Mechanical and thermal expansion behavior of hipped aluminum-TiB2 com- posites," Materials Chemistry and Physics, vol. 97, no. 1, pp. 91-97, 2006.

[57] S. Madhavan, S. Balasivanandha Prabu, and K. A. Padmanabhan, "On the role of process parameters of aluminothermic reaction synthesis of in-situ Al-TiB2 composites: microstructure and mechanical proper- ties," Letters on Materials, vol. 4, no. 2, pp. 84-88, 2014.

[58] A. Mandal, M. Chakraborty, and B. S. Murty, "Effect of TiB2 particles on sliding wear behaviour of Al-4Cu alloy," Wear, vol. 262, no. 1-2, pp. 160-166, 2007.

[59] N. B. Dhokey, "Effect of KBF4 and K2TiF6 on precipitation kinetics of TiB2 in aluminium matrix composite," Advanced Materials Letters, vol. 2, no. 3, pp. 210-216, 2011.

[60] S. Suresh, N. Shenbaga Vinayaga Moorthi, and C. Emmy Prema, "Tribological and mechanical behav- ior study of Al6061-TiB 2 metal matrix composites using stir casting," Advanced MateriAls Research, vol. 984-985, pp. 200-206, 2014.

[61] R. Shobha, K. R. Suresh, and H. B. Niranjan, "Mechanical and microstructural evaluation of InsituAluminium titanium boride composite processed by severe plastic deformation," Procedia Materials Science, vol. 5, pp. 281-288, 2014.

[62] L. ü Peng, X. Yue, H. Ru, and Y. Liang, "Microstructure and mechanical properties of B4C- TiB2-Al composites fabricated by vacuum infiltration," Rare Metals, vol. 29, no. 1, pp. 92-97, 2010.

[63] J. Onora, "High-temperature mechanical properties of aluminium alloys reinforced with titanium diboride (TiB2) particles," Rare Met, vol. 30, pp. 200-205, 2011.

[64] G. Mahajan, N. Karve, U. Patil, P. Kuppan, and K. Venkatesan, "Analysis of microstructure, hard- ness and wear of $\mathrm{Al}-\mathrm{SiC}-\mathrm{TiB}_{2}$ hybrid metal matrix composite," Indian Journal of Science and Technology, vol. 8, no. S2, p. 101, 2015.

[65] T. V. Christy, Production, Characterization and Friction Stir Welding of Al-TiB2 Metal Matrix Composite, Anna University, Chennai, 2010.

[66] N. B. Dhokey and K. K. Rane, "Wear behavior and its correlation with mechanical properties of TiB2Reinforced aluminium-based composites," Advances in Tribology, vol. 2011, Article ID 837469, 8 pages, 2011.

[67] V. Mohanavel, "Mechanical and microstructural characterization of AA7178-TiB2 composites," Materials Testing, vol. 62, no. 2, pp. 146-150, 2020.

[68] K. L Tee, L. Lu, and M. O Lai, "Synthesis of in situ Al-TiB2 composites using stir cast route," Composite Structures, vol. 47, no. 1-4, pp. 589-593, 1999.
[69] S. Kumar, M. Chakraborty, V. Subramanya Sarma, and B. S. Murty, "Tensile and wear behaviour of in situ Al-7Si/ TiB2 particulate composites," Wear, vol. 265, no. 1-2, pp. 134-142, 2008.

[70] L. Lu, M. O. Lai, and F. L. Chen, "Al-4 wt\% Cu Composite reinforced with in-situ TiB2 particles," Acta Materialia, vol. 45, no. 10, pp. 4297-4309, 1997.

[71] M. Karbalaei Akbari, H. R. Baharvandi, and K. Shirvanimoghaddam, "Tensile and fracture behavior of nano/micro TiB2 particle reinforced casting A356 aluminum alloy composites," Materials \& Design, vol. 66, pp. 150-161, 2015.

[72] S. Suresh, N. Shenbaga Vinayaga Moorthi, S. C. Vettivel, N. Selvakumar, and G. R. Jinu, "Effect of graphite addition on mechanical behavior of Al6061/TiB2 hybrid composite using acoustic emission," Materials Sci- ence and Engineering: A, vol. 612, pp. 16-27, 2014.

[73] K. Sivaprasad, S. P. Kumaresh Babu, S. Natarajan, R. Narayanasamy, B. AnilKumar, and G. Dinesh, "Study on abrasive and erosive wear behaviour of $\mathrm{Al} 6063 / \mathrm{TiB} 2$ in situ composites," Materials Science and Engineering: A, vol. 498, no. 1-2, pp. 495-500, 2008.

[74] C. S. Ramesh and A. Ahamed, "Friction and wear behaviour of cast Al 6063 based in situ metal matrix composites," Wear, vol. 271, no. 9-10, pp. 1928-1939, 2011.

[75] K. Niranjan and P. R. Lakshminarayanan, "Optimization of process parameters for in situ casting of $\mathrm{Al} / \mathrm{TiB} 2$ composites through response surface methodology," Transactions of Nonferrous Metals Society of China, vol. 23, no. 5, pp. 12691274, 2013.

[76] S. Johny James, K. Venkatesan, P. Kuppan, and R. Ramanujam, "Hybrid aluminium metal matrix composite reinforced with SiC and TiB2," Procedia Engineering, vol. 97, pp. 1018-1026, 2014.

[77] C. M. Anand Partheeban, M. Rajendran, S. C. Vettivel, S. Suresh, and N. S. V. Moorthi, "Mechanical behav- ior and failure analysis using online acoustic emission on nanographite reinforced Al6061-10TiB2 hybrid composite using powder metallurgy," Materials Science and Engineering: A, vol. 632, pp. 1-13, 2015.

[78] X. Jing, W. Jun, H. Y. Feng, C. Chong, and Sb Ole, "Behaviour of $\mathrm{CeO} 2$ additive in in-situ TiB2 particles reinforced $\mathrm{Al}$ alloy composite," Trans Nonferrous Met Soc China, vol. 22, pp. 1012-1017, 2014.

[79] A. Mahamani, A. Karthik, S. Karthikeyan, P. Kathiravan, and Y. P. Kumar, "Synthesis, Quantitative elemen- tal analysis, Microstructure characteristics and micro hardness analysis of AA2219 aluminium alloy matrix composite reinforced by Insitu TiB2 and sub-micron ZrB2 particles," in Proceedings of the Frontiers in Automobile and Mechanical Engineering, pp. 50-53, IEEE, Chennai,India, Nov 2010.

[80] J. Xue, J. Wang, Y. Han, L. Pan, and B. Sun, "Effects of CeO2 additive on the microstructure and mechanical properties of in situ TiB2/Al composite," Journal of Alloys and Compounds, vol. 509, no. 5, pp. 1573-1578, 2011.

[81] A. Mandal, B. S. Murty, and M. Chakraborty, "Sliding wear behaviour of T6 treated A356-TiB2 in-situ composites," Wear, vol. 266, no. 7-8, pp. 865-872, 2009.

[82] S. C Tjong and K. C Lau, "Properties and abrasive wear of TiB 2/Al-4\%Cu composites produced by hot iso- static pressing," Composites Science and Technology, vol. 59, no. 13, pp. 2005-2013, 1999. 
[83] S. J. Vijay, "Investigation on Al6061-TiB2 in-situ metal matrix composite," Production, Friction Stir Welding and Characterization, Anna University, Chennai, 2014.

[84] A. Mandal, M. Chakraborty, and B. S. Murty, "Ageing behaviour of A356 alloy reinforced with in-situ formed TiB2 particles," Materials Science and Engineering: A, vol. 489, no. 1-2, pp. 220-226, 2008.

[85] H. B. Michael Rajan, I. Dinaharan, S. Ramabalan, and E. T. Akinlabi, "Influence of friction stir processing on microstructure and properties of AA7075/TiB 2 in situ composite," Journal of Alloys and Compounds, vol. 657, pp. 250-260, 2016.

[86] T. Hong, X. Li, H. Wang, and D. Chen, "Influence of solution temperature on microstructure and properties of in-situ TiB2/ 2009 composites," Mater Sci Eng A, vol. 634, pp. 1-4, 2015.

[87] D. Dey, A. Bhowmik, and A. Biswas, "Wear behavior of stir casted aluminum-titanium diboride (Al2024-TiB2) composite," Materials Today: Proceedings, vol. 26, pp. 1203-1206, 2020.

[88] D. Sethi, S. Kumar, S. Choudhury, S. Shekhar, and B. S. Roy, "Synthe- sis and characterization of AA7075/TiB2 aluminum matrix composite formed through stir casting method," Materials Today: Proceedings, vol. 26, pp. 1908-1913, 2020. 